\title{
Antarctic sponges (Porifera, Demospongiae) of the South Shetland Islands and vicinity. Part I. Spirophorida, Astrophorida, Hadromerida, Halichondrida and Haplosclerida ${ }^{1}$
}

\author{
Maurício Campos ${ }^{2}$; ; Beatriz Mothes $^{2}$ \& Inga L. Veitenheimer Mendes ${ }^{3}$
}

\begin{abstract}
${ }^{1}$ Contribution number 510 of the Programa de Pós-Graduação em Biologia Animal, Instituto de Biociências, Universidade Federal do Rio Grande do Sul.

${ }^{2}$ Museu de Ciências Naturais, Fundação Zoobotânica do Rio Grande do Sul. Rua Salvador França 1427, 90690-000 Porto Alegre, Rio Grande do Sul, Brasil.E-mail: mrcpoa@hotmail.com; bmothes@fzb.rs.gov.br

3 Programa de Pós-Graduação em Biologia Animal, Universidade Federal do Rio Grande do Sul. Avenida Bento Gonçalves 9500,91501-970 Porto Alegre, Rio gRande do Sul, Brasil.E-mail: inga.mendes@ufrgs.br
\end{abstract}

\begin{abstract}
The aim of this work is to redescribe 11 species of sponges collected through the Brazilian Antarctic Program (PROANTAR), at the South Shetland Islands and vicinity. New information is provided on the Antarctic sponge fauna, in regard to species richness and the geographical and bathymetric distributions of identified species. The following species were identified and are here illustrated and fully described: Cinachyra antarctica (Carter, 1872), Cinachyra barbata Sollas, 1886, Craniella leptoderma (Sollas, 1886), Tethyopsis Iongispinum (Lendenfeld, 1907), Polymastia invaginata Kirkpatrick, 1907, Homaxinella balfourensis (Ridley \& Dendy, 1886), Suberites montiniger Carter, 1880, Halichondria (Eumastia) attenuata (Topsent, 1915), Haliclona (Soestella) chilensis (Thiele, 1905), Hemigellius bidens (Topsent, 1901) and Calyx arcuarius (Topsent, 1913). Two new records are given for the Antarctic continent: Halichondria (Eumastia) attenuata (Topsent, 1915) and Haliclona (Soestella) chilensis (Thiele, 1905). Tethyopsis Iongispinum (Lendenfeld, 1907), Suberites montiniger Carter, 1880 and Hemigellius bidens (Topsent, 1901) represent the first records for this sector of the continent. Bathymetric data are extended for $T$. longispinum and $H$. attenuata.
\end{abstract}

KEY WORDS. Antarctica; PROANTAR; taxonomy.

RESUMO. Esponjas Antárticas (Porifera, Demospongiae) das Ilhas Shetland do Sul e áreas próximas. Parte I. Spirophorida, Astrophorida, Hadromerida, Halichondrida e Haplosclerida. O objetivo deste trabalho é redescrever 11 espécies de esponjas coletadas através do Programa Antártico Brasileiro (PROANTAR), nas Is. Shetland do Sul e áreas próximas. Nnovas informações são fornecidas acerca do conhecimento da fauna de poríferos da Antártica, tanto para a riqueza específica como para os dados referentes às distribuições geográfica e batimétrica das espécies identificadas. As seguintes espécies foram identificadas e são aqui ilustradas e amplamente descritas: Cinachyra antarctica (Carter, 1872), Cinachyra barbata Sollas, 1886, Craniella leptoderma (Sollas, 1886), Tethyopsis Iongispinum (Lendenfeld, 1907), Polymastia invaginata Kirkpatrick, 1907, Homaxinella balfourensis (Ridley \& Dendy, 1886), Suberites montiniger Carter, 1880, Halichondria (Eumastia) attenuata (Topsent, 1915), Haliclona (Soestella) chilensis (Thiele, 1905), Hemigellius bidens (Topsent, 1901) and Calyx arcuarius (Topsent, 1913). Duas espécies são pela primeira vez registradas para o continente antártico, Halichondria (Eumastia) attenuata (Topsent, 1915) e Haliclona (Soestella) chilensis (Thiele, 1905), enquanto que Tethyopsis Iongispinum (Lendenfeld, 1907), S. montiniger Carter, 1880 e Hemigellius bidens (Topsent, 1901) apresentam o primeiro registro para este setor do continente. Ampliam-se ainda os dados batimétricos para $T$. longispinum e $H$. attenuata.

PALAVRAS-CHAVE. Antártica; PROANTAR; taxonomia.

Sponges comprise an important element of the Antarctic biota, because of their significant species diversity and the presence of communities predominantly consisting of sponges in some areas of the continent. Sponges are one of the most characteristic groups of this benthic fauna, together with Bryozoa and Echinodermata; this part of the world is probably the only region where the sponges can be found in constant abundance over a large area (KoLTun 1969). Literature records indicate a total of 352 species of Antarctic demosponges (McCuntock et al. 2005). In depths around $100 \mathrm{~m}$, sponges can reach biomass values comparable to the highest levels observed in tropical areas (SARÀ et al. 1992).

Revista Brasileira de Zoologia 24 (3): 687-708, setembro 2007 
According to Calcinai \& Pansini (2000), Antarctic sponges are relatively well known; however, the continent is so extensive that any new study, even in small areas, will add significantly to present knowledge of this group. Although many scientific expeditions have been conducted since the $19^{\text {th }}$ century, there are still some areas where the sponge fauna is little known, such as the South Shetland Islands and vicinity (Ríos et al. 2004). In this region, 86 species from 51 genera had been recorded (extrapolated from data of SARÀ et al. 1992).

The aim of the present study was to provide a full description of the Porifera collected in the ocean area explored by the Brazilian Antarctic Program, at the South Shetland Islands (Elephant I., King George I. and Livingston I) and Bransfield Strait.

\section{MATERIAL AND METHODS}

The samples were collected through the Brazilian Antarctic Program, at the South Shetland Islands and in the Bransfield Strait $\left(61^{\circ} 02^{\prime}-63^{\circ} 44^{\prime} \mathrm{S} / 54^{\circ} 16^{\prime}-62^{\circ} 31^{\prime} \mathrm{W}\right)$ (Fig. 1). Situated north of the Antarctic Peninsula, this island group consists of an archipelago formed by King George, Elephant and Livingston islands, together with other, smaller islands. Sampling was carried out on board the R/V "Professor Besnard," between 20 to $412 \mathrm{~m}$ depth, by beam-trawl, otter-trawl, SCUBA diving and other, unspecified collection methods.

Taxonomic study was based on the spicules, by dissociated spicule mounts and thick sections of the skeleton, following Mothes-De-Moraes (1978) and Mothes et al. (2004), respectively. Preparations for SEM study followed SiLva \& Mothes (1996). Spicule measurements are presented as minimum, mean, and maximum lenght, width after the slash $(/), \mathrm{N}=50$. The specimens were preserved in $96^{\circ} \mathrm{GL}$ alcohol and deposited in the Porifera Collection of Museu de Ciências Naturais, Fundação Zoobotânica do Rio Grande do Sul, Porto Alegre, RS, Brazil (MCNPOR).

Other abbreviation used in the text is BMNH (The Natural History Museum, London, England).

\section{RESULTS}

\section{Spirophorida Bergquist \& Hogg, 1969 Tetillidae Sollas, 1886 \\ Cinachyra antarctica (Carter, 1872) \\ Figs 2-11, Tab. I}

Tethya antarctica Carter, 1872: 412, pl. XX, figs 1-10.

Cinachyra antarctica; Burton, 1932: 264, 1938: 5; Koltun, 1976:

167; Desqueyroux, 1975: 55, pl. I, figs 10-12; DesqueyrouxFaúndez, 1989: 104, pl. 1, figs 3a-c, pl. 6, figs 33-34; Barthel et al., 1990: 122, 1997: 47; Gutt \& Koltun, 1995: 230.

Further synonym see Desqueyroux (1975).

Material studied. MCNPOR 1959, St. 4873, Bransfield Strait: $63^{\circ} 25^{\prime} \mathrm{S}-62^{\circ} 05^{\prime} \mathrm{W}, 66 \mathrm{~m}, 13 . \mathrm{II} .1986$, PROANTAR IV; MCNPOR 1978, 1980, St. 4874, Bransfield Strait: 63²5'S-

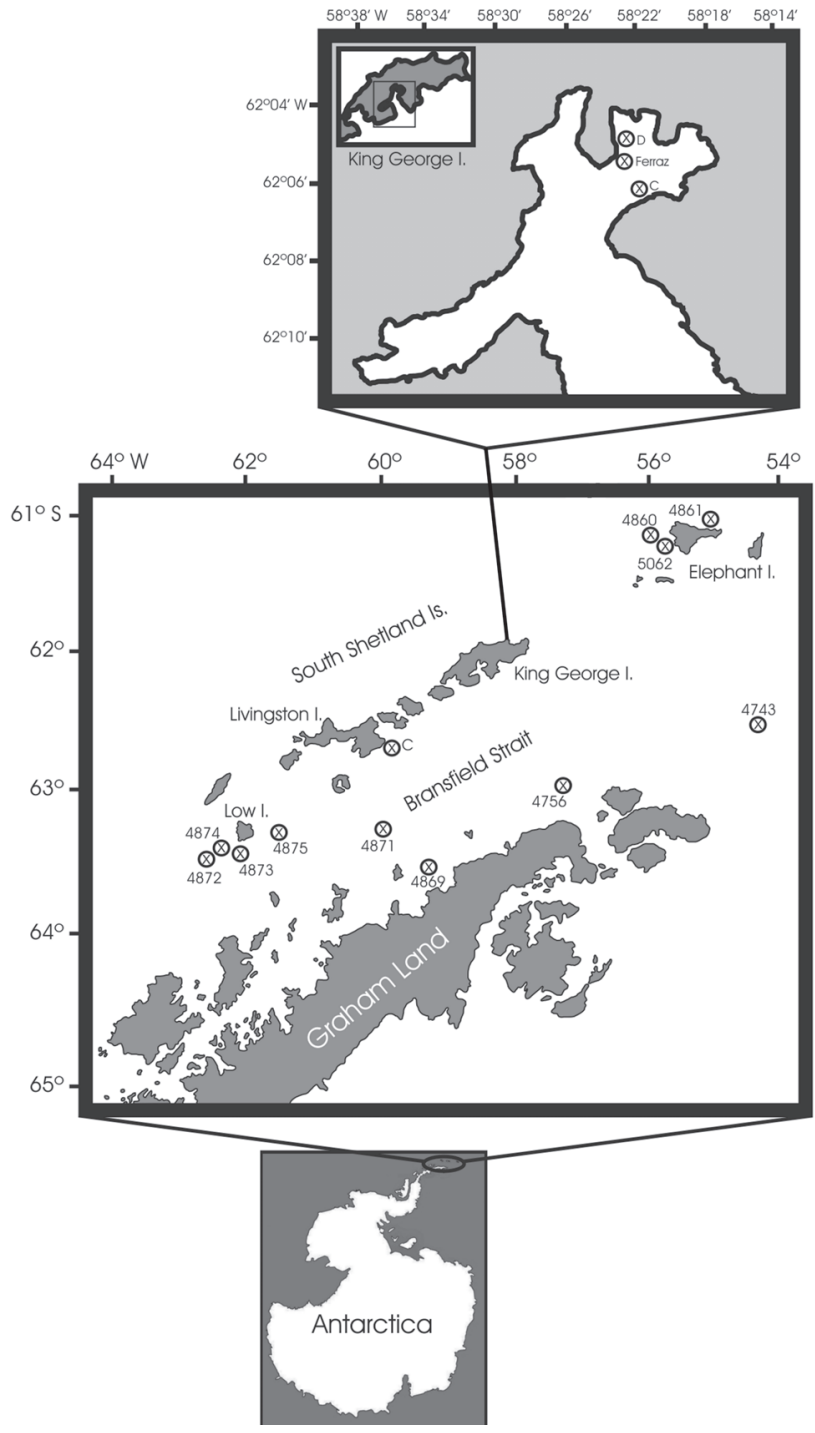

Figure 1. Location of the collecting area.

62 ${ }^{\circ} 19^{\prime} \mathrm{W}, 135 \mathrm{~m}, 14 . \mathrm{II} .1986$, PROANTAR IV.

Material examined for comparison. Cinachyra antarctica (Carter, 1872), collected by Mawson Antarctic Expedition, locality unknown, slide BMNH 1935.10.26.53.

Description. (MCNPOR 1959) (Fig. 2) Oval specimen; dimensions, in $\mathrm{cm}$ : 4.8 diameter, 7.0 height; surface with protruding spicules in long bundles, up to $2.0 \mathrm{~cm}$ lenght; oscules not observed; abundant pores $(<0.1 \mathrm{~cm}$ in diameter), mainly in the lateral portion. Preserved material firm in consistency; colour beige. MCNPOR 1978 consists of two individuals, both of globular format, bearing the same details in comparison to MCNPOR 1959, however their superficial spicule bundles are not so long $(<1.0$ $\mathrm{cm}$ ); dimensions, in cm: $1.4 \times 1.1$, and 0.9 x 0.8. MCNPOR 1980 is identical to MCNPOR 1959; dimensions, in cm: 3.7 x 2.6 x 2.4.

Revista Brasileira de Zoologia 24 (3): 687-708, setembro 2007 

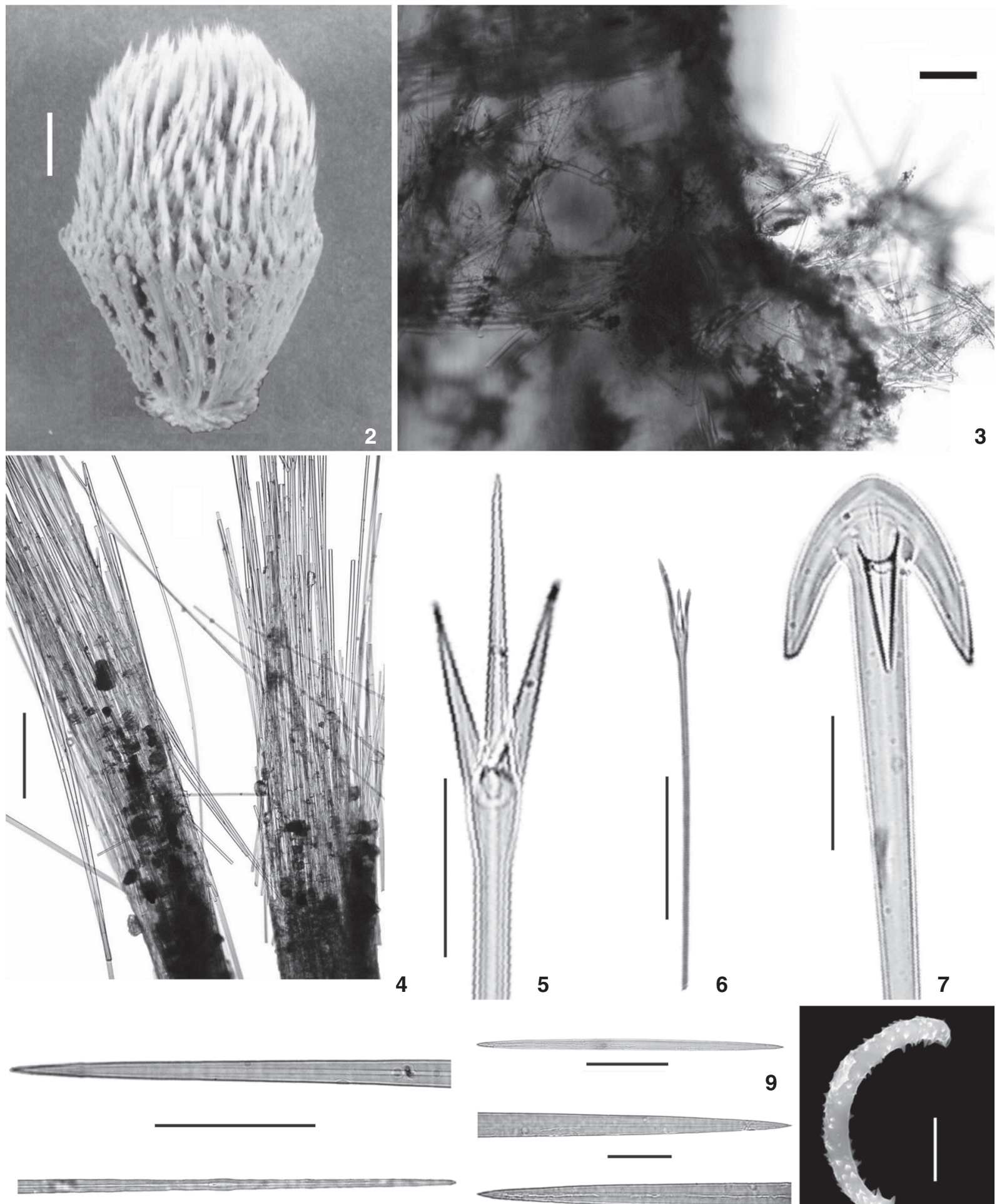

8
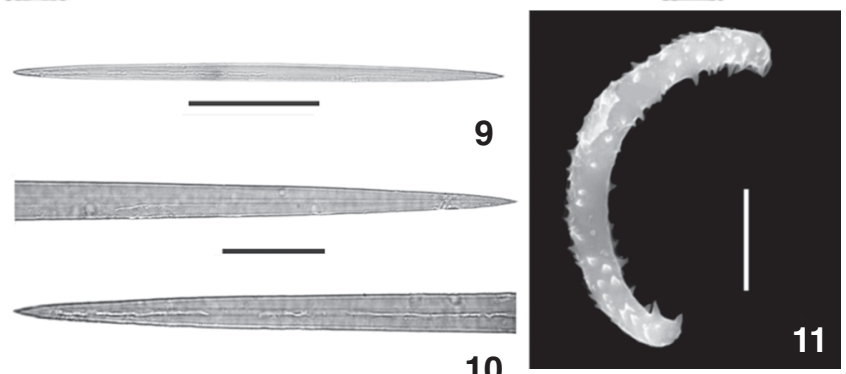

Figures 2-11. Cinachyra antarctica: (2) preserved specimen; (3) ectosomal arrangement of the skeleton; (4) choanosomal tracts; (5) protriaene I; (6) protriaene II; (7) anatriaene; (8) oxea I; (9) oxea II; (10) detail of oxea II extremities; (11) sigmaspire. Scale bars: (2) 1 cm; (3) $300 \mu \mathrm{m}$; (4) $750 \mu \mathrm{m}$; (5), (6), (7) $100 \mu \mathrm{m}$; (8), (9) $200 \mu \mathrm{m}$; (10) $50 \mu \mathrm{m}$; (11) $5 \mu \mathrm{m}$. 


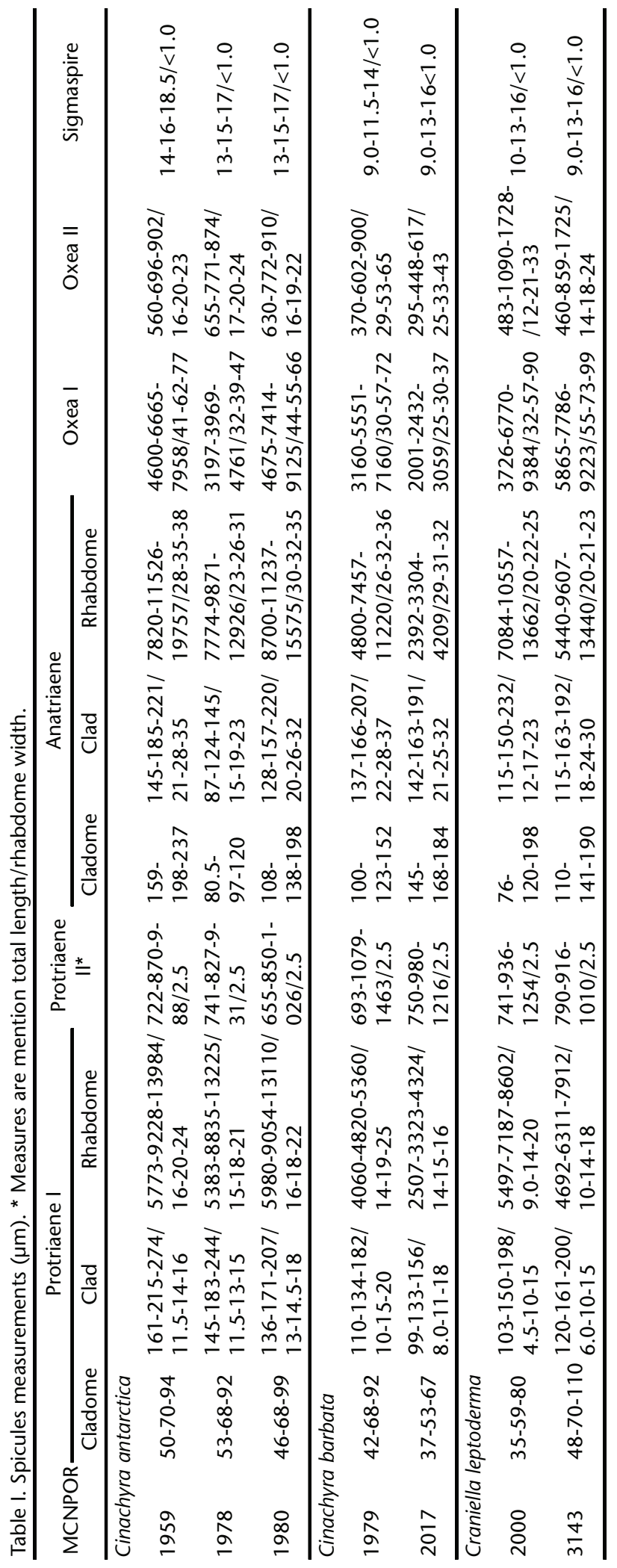

Skeleton. Ectosome constituted by oxeas II densely disposed, perpendicular to the surface (Fig. 3). Choanosome formed by thick radial tracts of protriaenes I, anatriaenes e oxeas I (420-810 $\mu \mathrm{m}$ thickness), which protrude at the surface (Fig. 4); between the tracts it can be observed oxeas I, II, protriaenes II and sigmaspires randomly arranged.

Spicules. Megascleres: protriaenes I - with clads of varied length (136-189.6-274/11.5-13.8-18 $\mu \mathrm{m}$ ) cladome 46-68.7-99 $\mu \mathrm{m}$, rhabdome long, straight and sinuous, filiform at terminal portion (Fig. 5) (5383-9039-13984/15-18.6-24 $\mu \mathrm{m}$ ); protriaenes II cladome and rhabdome similar to protriaenes I (Fig. 6) (655-8491026/2.5 $\mu \mathrm{m})$; anatriaenes - cladome (80.5-144.3-237 $\mu \mathrm{m})$ with uniform clads (87-155.3-221/15-24.3-35 $\mu \mathrm{m})$, with a slight apical prominence at their medium portion (Fig. 7), rhabdome long, straight and sinuous (7774-10878-19757/23-31-35 $\mu \mathrm{m})$; oxeas I straight, acerate extremities, some of them slightly blunt (Fig. 8) (3197-6016-9125/32-52-77 $\mu \mathrm{m}$ ); oxeas II - straight (Fig. 9), acerate extremities (Fig. 10) (560-746.3-910/16-19.6-24 $\mu \mathrm{m})$. Microscleres: sigmaspires (Fig. 11) - often in "C", a few in "S" shape (13-15.3$18.5 /<1.0 \mu \mathrm{m})$. All measurements are given in table I.

Remarks. BurTon (1929) included the species in Cinachyra, considering C. vertex Lendenfeld, 1907 as a synonym of $C$. antarctica, and alleged that the absence of sigmaspires described by CARTER (1872) for the holotype could not be correct. KolTUN (1964) included in the synonymy the variety monticularis, proposed by КіткратRICK (1908), who observed different patterns of pores and oscules; however, these characters were not strong enough to allow the taxa to be considered distinct.

The material examined for comparison is very similar to the collected material.

Distribution. Indian Ocean: Kerguelen I. (CARTER 1879). South America: South Georgia I. (BURTON 1932). Antarctica: Ross Sea (CARTER 1872, Sollas 1888); Victoria Land (KirKPatricK 1908, Broendsted 1926, Burton 1929, Koltun 1964); Adelie Land (BuRton 1938, Vacelet \& Arnaud 1972); Wilhelm II Land (Lendenfeld 1907); McRobertson Land (KolTuN 1964); Enderby Land (KolTuN 1976); Graham Land (Topsent 1917, Desqueyroux 1972); Weddell Sea (Barthel et al. 1990, 1997, GutT \& Koltun 1995); South Shetland Is.: Low I. (Desqueyroux 1975); Bransfield Strait (Desqueyroux-Faúndez 1989, present study). Bathymetry: $18 \mathrm{~m}$ (Kirkpatrick 1908) to $830 \mathrm{~m}$ (Gutt \& Koltun 1995).

\section{Cinachyra barbata Sollas, 1886 Figs 12-20, Tab. I}

Cinachyra barbata Sollas, 1886: 183; Burton, 1932: 265, 1940: 98; Koltun, 1976: 167; Desqueyroux, 1975: 55, pl. I, figs 1012; Desqueyroux-Faúndez, 1989: 103, pl. 1, figs 2a-e, pl. 6, figs 32; Barthel et al., 1990: 122, 1997: 47; Sarà et al. 1990: 252; Pansini et al., 1994: 68, fig. 4, pl. I, figs 3a-d; Gutt \& Koltun, 1995: 230; Cattaneo-Vietti et al., 1999: 540.

Further synonym see Desqueyroux $(1975,1989)$.

Material studied. MCNPOR 1979, 2017, St. 4874, Bransfield Strait: $63^{\circ} 25^{\prime} \mathrm{S}-62^{\circ} 19^{\prime} \mathrm{W}, 135$ m, 14.II.1986, PROANTAR IV. 

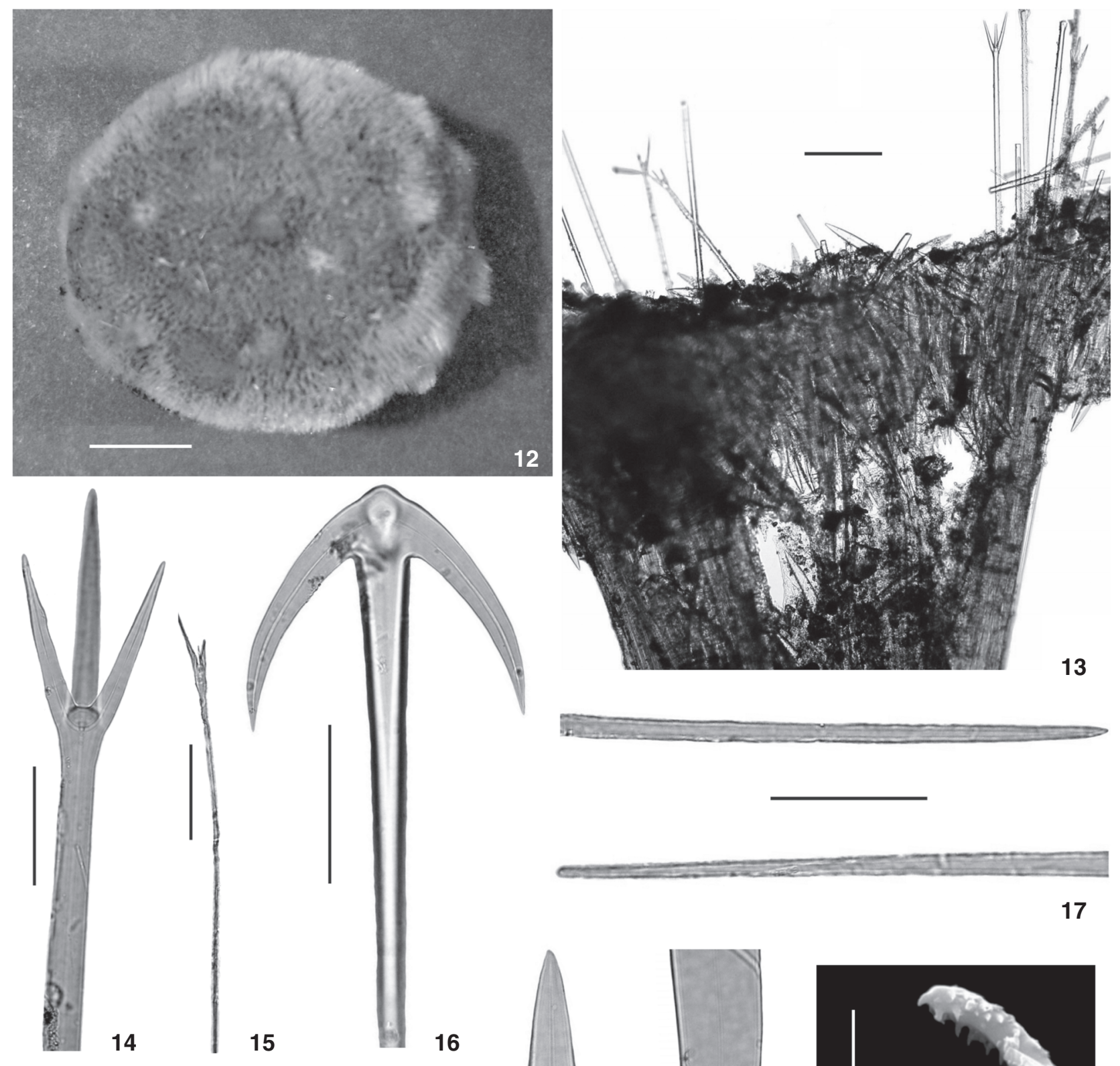

17
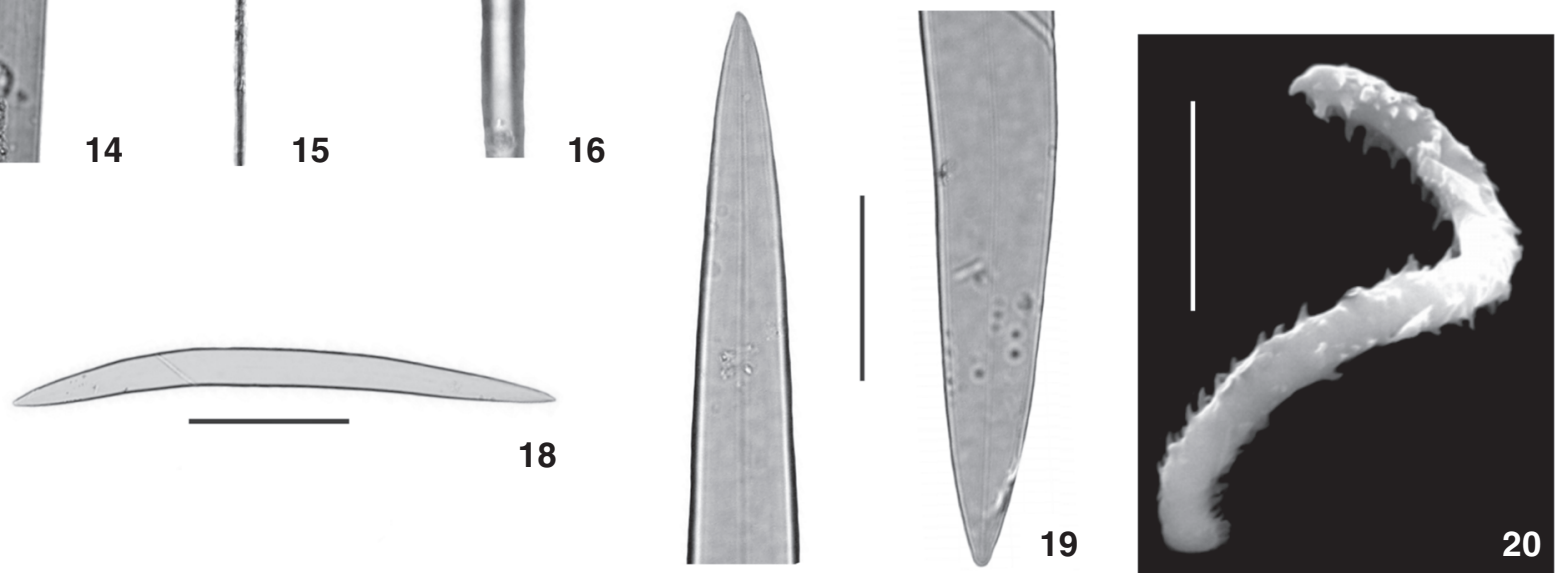

Figures 12-20. Cinachyra barbata: (12) preserved specimen; (13) skeleton; (14) protriaene I; (15) protriaene II; (16) anatriaene; (17) oxea l; (18) oxea II; (19) detail of oxea Il extremities; (20) sigmaspire. Scale bars: (12) $1 \mathrm{~cm}$; (13) $500 \mu \mathrm{m}$; (14) $150 \mu \mathrm{m}$; (15) $75 \mu \mathrm{m}$; (16) $150 \mu \mathrm{m}$; (17) $100 \mu \mathrm{m}$; (18) $300 \mu \mathrm{m}$; (19) $100 \mu \mathrm{m}$; (20) $5 \mu \mathrm{m}$. 
Material examined for comparison. Cinachyra barbata Sollas, 1886, collected by Antarctic Discovery Expedition, locality unknown, slide BMNH 1908.2.5.52g-x.

Description. (MCNPOR 1979) (Fig. 12) Globular specimen; dimensions, in cm: 2.5 height, 3.5 width, 3.2 thickness; hispid surface; oscules regularly distributed $(0.1-0.25 \mathrm{~cm}$ in diameter), surrounded by spicule brushes that reach $0.2 \mathrm{~cm}$ in height; pores not observed. Preserved material slightly compressible in consistency; colour grey with some cleared areas beige. MCNPOR 2017 a small sample, with the same characteristics presented by MCNPOR 1979, dimensions, in $\mathrm{cm}: 1.2$ height, 1.0 width, 0.8 thickness; two oscules observed (0.1-0.3 $\mathrm{cm}$ in diameter).

Skeleton. (Fig. 13) Thick cortex, formed by oxeas II in palisade, perpendicular to the surface. Choanosome constituted by radial spicule tracts formed by protriaenes, anatriaenes and oxeas I (120-500 $\mu \mathrm{m}$ thickness), from the basal portion towards the surface, crossing the cortex and protruding the surface. Sigmaspires and protriaenes II dispersed along the skeleton.

Spicules. Megascleres: protriaenes I - with clads of varied length (Fig. 14) (99-133.5-182/8.0-13-20 $\mu \mathrm{m})$, cladome 37-60.5$92 \mu \mathrm{m}$, rhabdome long and straight (2507-4071.5-5360/14-17$25 \mu \mathrm{m}$ ); protriaenes II - cladome identical to protriaenes I (Fig. $15)$, rhabdome generally filiform and sinuous toward the terminal portion (693-1029.5-1463/2.5 $\mu \mathrm{m})$; anatriaenes - cladome (100-145.5-184 $\mu \mathrm{m})$ with clads (137-164.5-207/21-26.5-37 $\mu \mathrm{m})$ lightly curved toward the rhabdome (Fig. 16), extremity sinuous and filiform (2392-5380.5-11220/26-31.5-36 $\mu \mathrm{m})$; oxeas I - slightly curved, acerate points, a few blunted (Fig. 17) (20013976.5-7160/25-43.5-72 $\mu \mathrm{m}$ ); oxeas II - slightly curved (Fig. 18), acerate extremities (Fig. 19) (295-525-900/25-43-65 $\mu \mathrm{m}$ ). Microscleres: sigmaspires (Fig. 20) - morphology varying from "C" to twisted forms $(9.0-12.3-16 /<1.0 \mu \mathrm{m})$. All measurements are given in table. I.

Remarks. SolLas (1888) provided an extensive and detailed description of almost all the morphological characteristics, and KiRKPATRICK (1905) extended the description with additional details on the oscules and other surface structures, which were also observed in the samples studied for this report.

Although there may be doubt in regard to the valid species of Cinachyra, in the present study C. barbata and C. antactica were treated as separate species, because of the existence of at least two distinctive morphological characteristics (external morphology, size and shape of oxeas II), observed not only in the newly collected specimens but also in the comparative material. VAN SoEst \& RÜTZLER (2002) cited in the diagnosis of the genus the existence of only one species (in this case $C$. barbata); however, until now the two species have not been formally synonymized.

Distribution. Indian Ocean: Kerguelen I. (Sollas 1886, 1888, Lendenfeld 1907, Boury-Esnault \& Van Beveren 1982). South America: South Georgia I. (Burton 1932, 1940). Antarctica: Victoria Land (KirKPATRICK 1908, Burton 1929, SARÀ et al. 1990,
Pansini et al. 1994, Cattaneo-Vietti et al. 1999); Wilhelm II Land (Koltun 1964); McRobertson Land; Enderby Land (Koltun 1976); Weddell Sea (BARTHEl et al. 1990, 1997, Gutt \& Koltun 1995); South Shetland Is.: Robert I.; King George I. (DesqueyrouxFAÚNDEZ 1989); Bransfield Strait (present study); Deception I. (Desqueyroux 1975). Bathymetry: $2 \mathrm{~m}$ (Koltun 1976) to $830 \mathrm{~m}$ (Gutt \& Koltun 1995).

\section{Craniella leptoderma (Sollas, 1886) Figs 21-29, Tab. I}

Tetilla leptoderma Sollas, 1886: 179; Burton, 1929: 418; Koltun, 1976: 166; Desqueyroux \& Moyano, 1987: 47; DesqueyrouxFaúndez, 1989: 102, pl. I, figs 1a-d, pl. V, figs 26-28; Sarà et al., 1990: 252; Barthel et al., 1990: 122, 1997: 47; Gutt \& Koltun, 1995: 230; Cattaneo-Vietti et al., 1999: 540.

Further synonym see Burton (1929) and Desqueyroux-Faúndez (1989).

Material studied. MCNPOR 2000, St. 4861, Elephant I.:

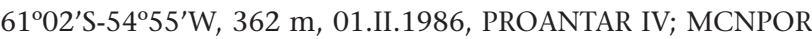

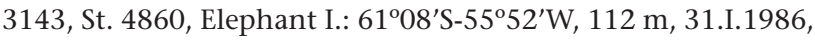
PROANTAR IV.

Description. (MCNPOR 3143) (Fig. 21) Fragment; dimensions, in cm: 2.8 height, 2.2 width, 0.65 thickness; hispid surface; pores and oscules not observed. Preserved material hard in consistency; colour brown. MCNPOR 2000 an amorphous, damaged fragment, formed by disperse spicule tracts, with exogenous material, colour grey; dimensions, in cm: 4.8 height, 3.4 width, 0.8 thickness.

Skeleton. (Fig. 22) Cortical region composed by oxeas II in parchment; it was also observed a small amount of foreign material. Choanosome made by thick longitudinal multispicular tracts of oxeas I and anatriaenes (250-530 $\mu \mathrm{m}$ thickness), radially disposed, originating from the basal portion until the surface, where it protrudes considerably. Microscleres and protriaenes II dispersed along the choanosome, mainly between the tracts.

Spicules. Megascleres: protriaenes I - cladome (35-64.5$110 \mu \mathrm{m})$ often with unequal clads (103-155.5-200/4.5-10-15 $\mu \mathrm{m})$ (Fig. 23), rhabdome long, straight, extremity sharp-pointed and sinuous (4692-6749-8602/9.0-14-20 $\mu \mathrm{m})$; protriaenes II cladome similar to protriaene I (Fig. 24), rhabdome thin and sinuous (741-926-1254/2.5 $\mu \mathrm{m})$; anatriaenes - cladome 76130.5-198 $\mu \mathrm{m}$, with uniform clads (115-156.5-232/12-20.5-30 $\mu \mathrm{m})$ (Fig. 25), rhabdome identical to protriaenes (5440-1008213662/20-21.5-25 $\mu \mathrm{m}$ ); oxeas I - straight, conical and/or acerate extremities (3726-7278-9384/32-65-99 $\mu \mathrm{m}$ ) (Fig. 26); oxeas II straight or slightly curved (Fig. 27), with acerate extremities (483-974.5-1728/12-19.5-33 $\mu \mathrm{m}$ ) (Fig. 28). Microscleres: sigmaspires (Fig. 29) - in "C" shape, rarely in "S" (9.0-13-16/< $1.0 \mu \mathrm{m})$. All measurements are given in Tab. I.

Remarks. Although the two samples of $C$. leptoderma here identified are only fragments, it is possible to observe that it has certain variation in the external form for such species, cor- 

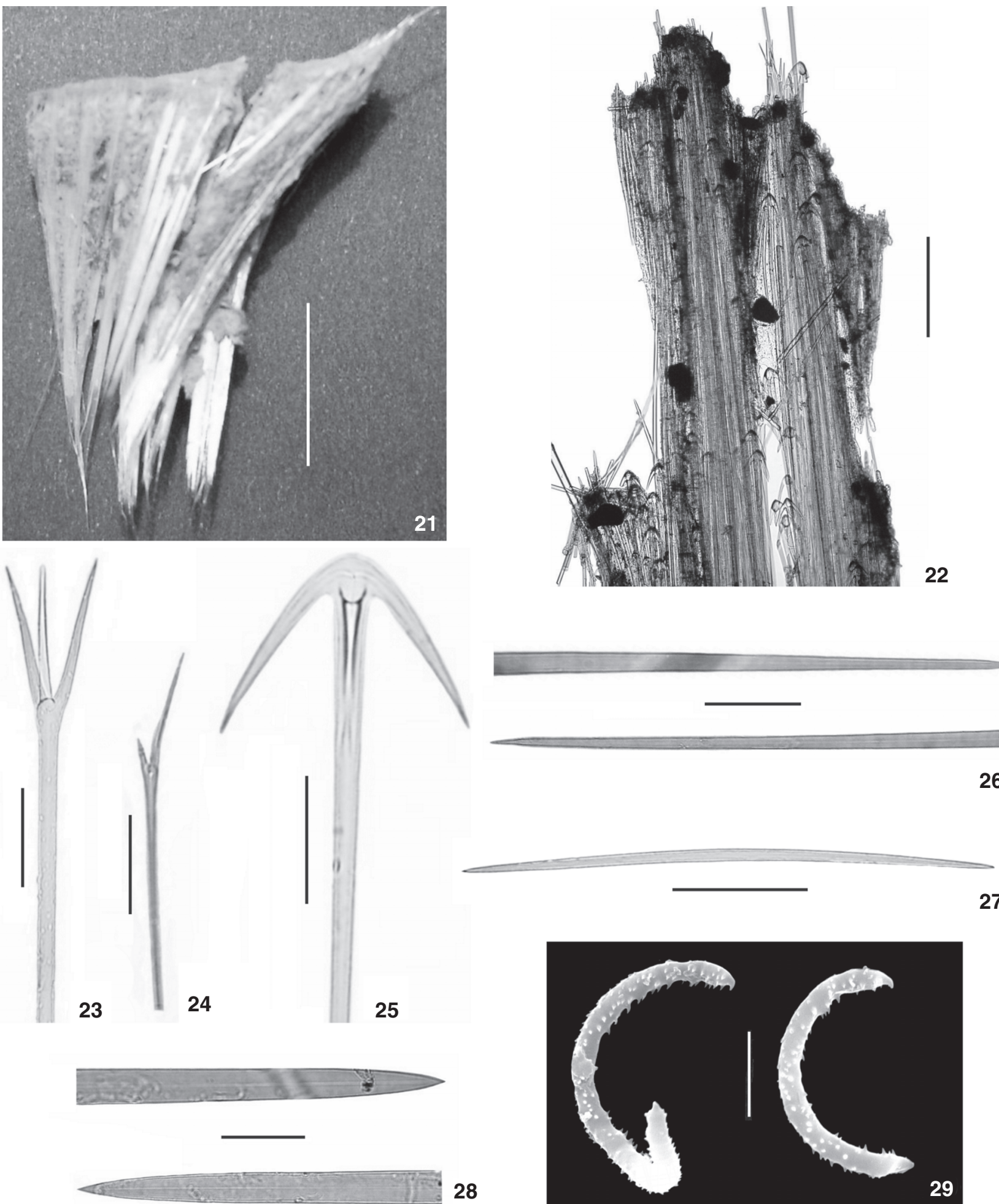

Figures 21-29. Craniella leptoderma: (21) preserved specimen; (22) skeleton; (23) protriaene I; (24) protriaene II; (25) anatriaene; (26) oxea I; (27) oxea II; (28) detail of oxea II extremities; (29) sigmaspire. Scale bars: (21) $1 \mathrm{~cm}$; (22) $750 \mu \mathrm{m}$; (23) $200 \mu \mathrm{m}$; (24) $50 \mu \mathrm{m}$; (25) $150 \mu \mathrm{m} ;(26),(27),(28) 300 \mu \mathrm{m}$; (29) $5 \mu \mathrm{m}$. 
roborating with the affirmation of Desqueyroux (1975). The two samples from the present study are a bit different; however the spicules are identical in both samples and confirm the identification.

According to VAN Soest et al. (2005), currently the species belongs to the genus Craniella.

Distribution. Indian Ocean: Kerguelen I. (BourY-EsNaulT \& Van Beveren 1982); Heard I.; Christmas I. (Sollas 1886, 1888). South America: Argentina (Sollas 1886, 1888); Chile (Desqueyroux \& Moyano 1987); Falkland Is.; South Georgia I. (Burton 1932). Antarctica: Victoria Land (KirkPatrick 1908 Broendsted 1926 Burton 1929, Sarà et al. 1990, Cattaneo-Vietti et al. 1999); Wilhelm II Land (Lendenfeld 1907); Adelie Land (BurTon 1938); McRobertson Land; Princess Elisabeth Land; Banzare Land; Clarie Land (Koltun 1964); Enderby Land; Sabrina Land (Koltun 1976); Graham Land (DesqueYroux-Faúndez 1989); Weddell Sea (BARThel et al. 1990, 1997, GutT \& Koltun 1995); South Shetland Is.: Greenwich I. (Desqueyroux 1975); King George I. (Koltun 1964); Clarence I. (Burton 1932); Elephant I. (present study). Bathymetry: 4 to 2267 m (Koltun 1976).

\section{Astrophorida Sollas, 1888 Ancorinidae Schmidt, 1870 Tethyopsis longispinum (Lendenfeld, 1907) Figs 30-37, Tab. II}

Tribrachion longispinum Lendenfeld, 1907: 322, pl. XXIV, figs 1-13. Monosyringa longispinna; Koltun, 1976: 166; Barthel et al., 1990: 122, 1997: 47; Gutt \& Koltun, 1995: 230.

Monosyringa broendstedi Burton, 1929: 415, pl. IV, fig. 1, textfig. 4.

Further synonym see Koltun (1976).

Material studied. MCNPOR 3164, St. Ferraz, King George I.: $62^{\circ} 05^{\prime}$ S-58 $23^{\prime}$ W, 20 m, 03.II.1985, PROANTAR III; MCNPOR 3123, St. 4743, Bransfield Strait: $62^{\circ} 30^{\prime} \mathrm{S}-54^{\circ} 16^{\prime} \mathrm{W}, 412 \mathrm{~m}$, 28.I.1985, PROANTAR III; MCNPOR 3121, Est. 4756, Bransfield Strait: $62^{\circ} 58^{\prime}$ S-5 $57^{\circ} 10^{\prime} \mathrm{W}, 70$ m, 02.II.1985, PROANTAR III.

Description. (MCNPOR 3123) (Fig. 30) Massive, amorphous fragment; dimensions, in cm: 6.8 x 3.4, 1.7 thickness; hispid surface; the surface has small tubular cylindrical projections (0.2-0.8 cm height), with the oscular openings on top $(0.1 \mathrm{~cm}$ in diameter). Preserved material firm in consistency; colour pinkish with greyish regions. MCNPOR 3121 and 3164 are identical to MCNPOR 3123, with same consistency and colour, as well as their superficial tubular projections; dimensions, in cm: $4.0 \times 2.2,1.8$ thickness, and $3.5 \times 3.0,2.5$ thickness, respectively.

Skeleton. (Fig. 31) Cortex composed by microscleres and cladomes of orthotriaenes, together with a great amount of exogenous material and spongin. Choanosome with radial arrangement, with megascleres arranged in multispicular tracts (230-500 $\mu \mathrm{m}$ thick), perpendicular to the sponge surface. Between the tracts there are abundant microscleres and spongin.

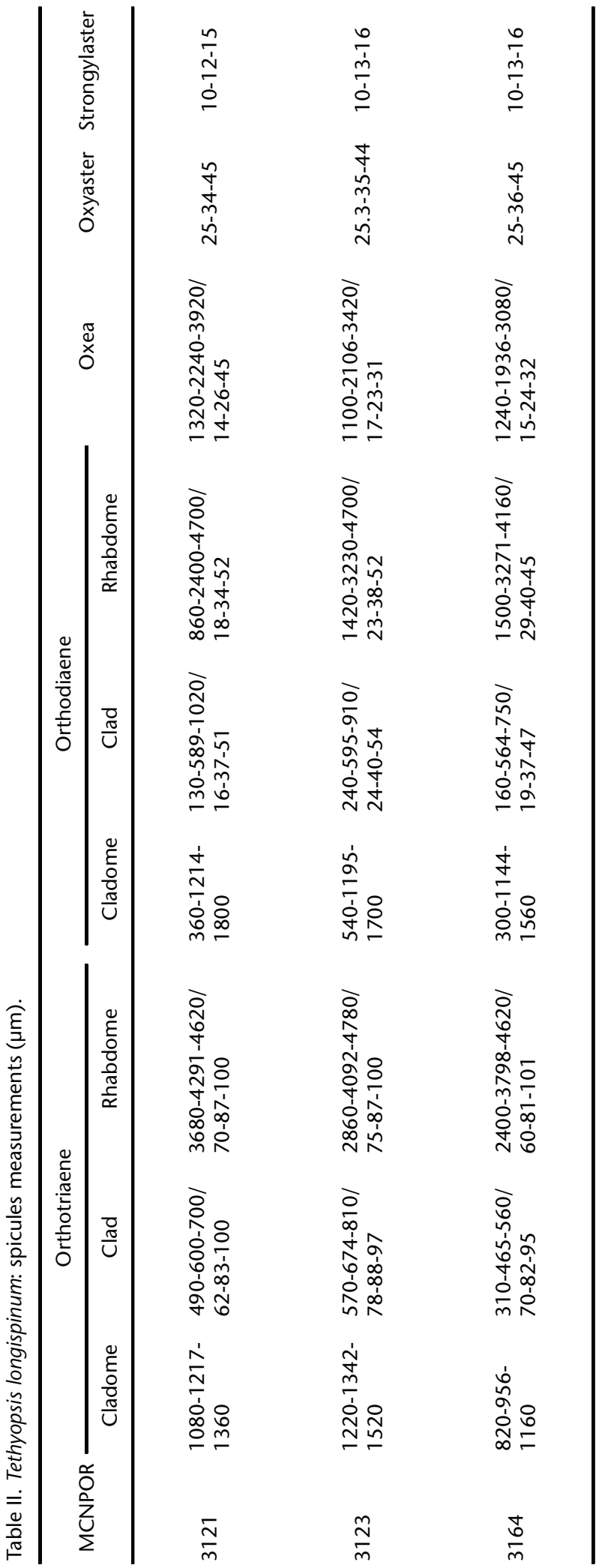



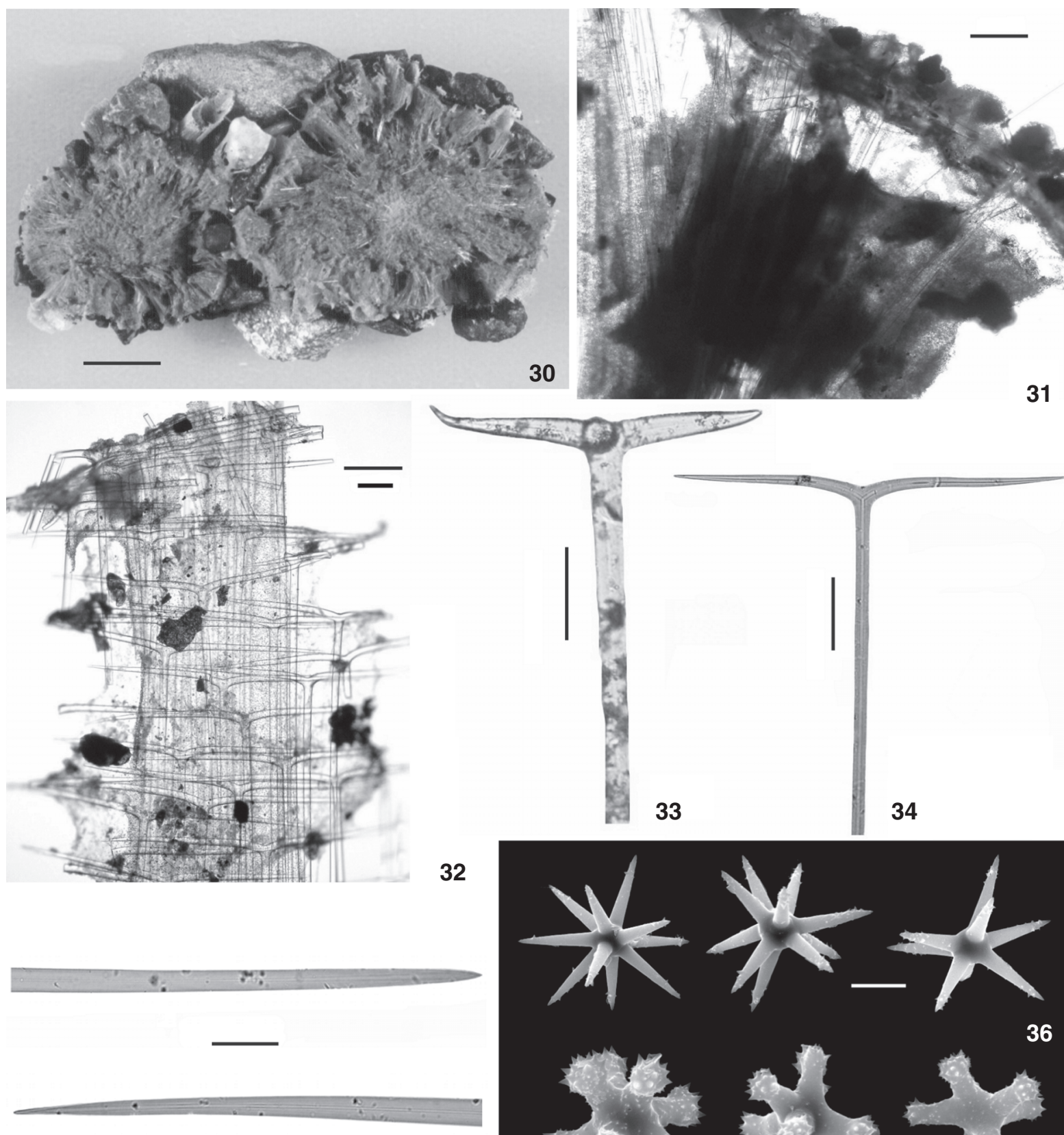

35

32
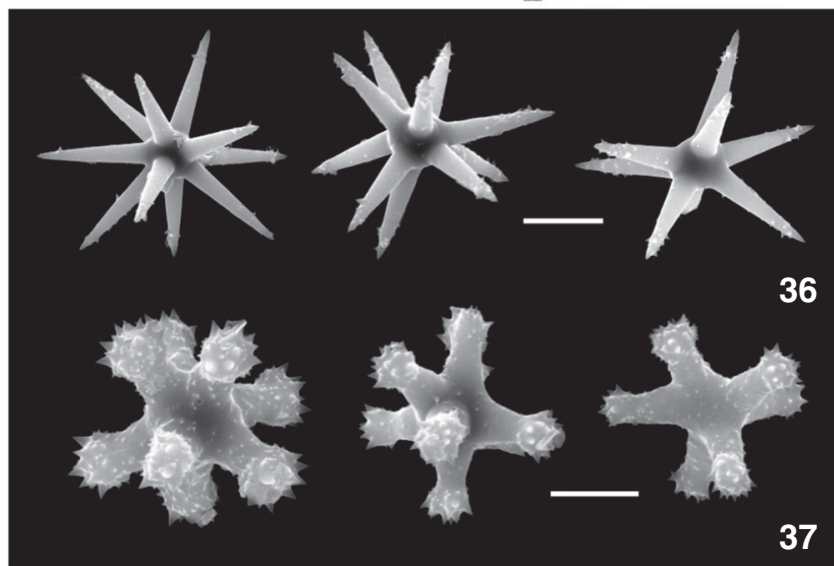

Figures 30-37. Tethyopsis longispinum: (30) preserved specimen; (31) skeleton; (32) spicular arrangement of tubular projections; (33) ortotriaene; (34) ortodiaene; (35) oxea; (36) oxyasters; (37) strongylasters. Scale bars: (30) $1 \mathrm{~cm}$; (31), (32), (33) 500 $\mu \mathrm{m}$; (34), (35) $300 \mu \mathrm{m}$; (36) $10 \mu \mathrm{m}$; (37) $5 \mu \mathrm{m}$.

Oscular projections are formed exclusively by an arrangement of orthodiaenes regularly overlapped (Fig. 32), involved in a fine membrane in which microscleres are present.
Spicules. Megascleres: orthotriaenes - cladome 10801171.6-1520 $\mu \mathrm{m}$, with often sinuous clads (310-579.6-810/6284.3-100 $\mu \mathrm{m}$ ) (Fig. 33), rhabdome with rounded apical extrem-

Revista Brasileira de Zoologia 24 (3): 687-708, setembro 2007 
ity (2400-4060.3-4620/60-85-101 $\mu \mathrm{m})$; orthodiaenes - cladome of varied angle (300-1184.3-1800 $\mu \mathrm{m})$, straight to sinuous clads (130-582.6-1020/16-38-54 $\mu \mathrm{m}$ ) (Fig. 34), rhabdome straight or

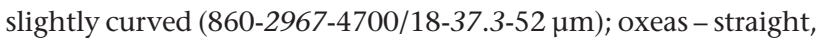
slightly to sharply curved; extremities varying from hastate to acerate (1100-2094-3920/14-24.3-45 $\mu \mathrm{m})$ (Fig. 35). Microscleres: oxyasters (Fig. 36) - 05-10 rays, slightly microspined, concentrated at apical portion (25-35-45 $\mu \mathrm{m}$ ); strongylasters (Fig. 37) 04-07 rays, bearing microspines at the apical portion of the rays (10-12.6-16 $\mu \mathrm{m})$. All measurements are given in Tab. II.

Remarks. According to Koltun (1964), Monosyringa broendstedi Burton, 1929 differs from T. longispinum only in having some bifurcation in regard to the clads of the triaenes and diaenes; this characteristic has no taxonomic value, being only a modified form.

This species tends to live totally embedded in the substrate, with only the papillae protruding (BARTHEL et al. 1991). It seems to have an important ecological role, providing a special environment for sea stars, which sometimes are concentrated over and between the papillae.

For the first time, SEM photomicrographs of microscleres are provided, making it possible to observe the microspine pattern and the arrangement of the rays in these spicules.

Distribution. Antarctica: Wilhelm II Land (Lendenfeld 1907); Victoria Land (BurTon 1929); McRobertson Land; Knox Land; Banzare Land (Koltun 1964); Enderby Land (Koltun 1976); Weddell Sea (BARThel et al. 1990, 1997, Gutt \& Koltun 1995); Bransfield Strait (present study); South Shetland Is.: King George I. (present study). Bathymetry: $20 \mathrm{~m}$ (present study) to $1340 \mathrm{~m}$ (Koltun 1964).

\section{Hadromerida Topsent, 1894 Polymastiidae Gray, 1867 Polymastia invaginata Kirkpatrick, 1907}

\section{Figs 38-44}

Polymastia invaginata Kirkpatrick, 1907: 271; Burton, 1929: 446, 1932: 338 1938: 19; Koltun, 1976: 168; Vacelet \& Arnaud, 1972: 14; Desqueyroux, 1976: 95; Desqueyroux \& Moyano, 1987: 47; Desqueyroux-Faúndez, 1989: 106, pl. II, figs 5a-d, pl. VI, figs 36-37; Barthel et al., 1990: 122, 1997: 47; Gutt \& Koltun, 1995: 230; Pansini \& Sarà, 1999: 205.

Further synonym see Desqueyroux-Faúndez (1989).

Material studied. MCNPOR 1976, St. 4874, Bransfield Strait: $63^{\circ} 25^{\prime}$ S-62 $2^{\circ} 19^{\prime} \mathrm{W}, 135$ m, 14.II.1986, PROANTAR IV.

Material examined for comparison. Polymastia invaginata Kirkpatrick, 1907, collected by Antarctic Discovery Expedition, locality unknown, slide BMNH 1908.2.5.76.

Description. (Fig. 38) Massive specimen; dimensions, in $\mathrm{cm}$ : 3.9 x 2.0, 1.7 thickness; hispid surface; papillae 0.1-0.25 $\mathrm{cm}$ height, with oscular openings at the apex $(0.1 \mathrm{~cm}$ in diameter). Preserved material firm, incompressible in consistency; external colour beige, darker internally.
Skeleton. (Fig. 39) Upper portion formed by the cortex, which is not easily detachable, 580-980 $\mu \mathrm{m}$ thickness, composed by ectosomal tylostyles in palisade, often with the apical extremity protruding through the surface. Choanosome formed by a radial arrangement of multispicular tracts, composed exclusively of choanosomal tylostyles; tracts $270-360 \mu \mathrm{m}$ thick. The spicular arrangement present in the papillae is composed of choanosomal tylostyles, positioned perpendicularly to the surface (Fig. 40).

Spicules. Megascleres: ectosomal tylostyles - straight or slightly curved, lightly swollen along the shaft (Fig. 41); tyle well defined (Fig. 42): 120-369.2-660/3.8-13.1-25 $\mu \mathrm{m}$, tyle width 5.0-9.4-12.5 $\mu \mathrm{m}$; choanosomal tylostyles - straight (Fig. 43), tyle poorly defined (Fig. 44); shaft a bit swollen below the tyle: 880-1400-1860/12.5-21.3-27.5 $\mu \mathrm{m}$, tyle width 10-13.4-16.3 $\mu \mathrm{m}$.

Remarks. Both the ectosomal and choanosomal tylostyles are smaller in comparison to previous records (KIRKPATRICK 1908, Koltun 1964, Desqueyroux 1976 Boury-Esnault \& Van Beveren 1982, Desqueyroux-Faúndez 1989). Only the measurements provided by Hentschel (1914), who proposed the variety gaussi, are similar to those obtained in the sample studied here. BurTON (1929) considered this to be intraspecific variation, and thought it unnecessary to create a new variety; this affirmation is corroborated by the present study.

Although there are small differences in the spicule sizes, the comparative material is quite similar to that observed in the present study, with respect to the general morphology of the spicules and the skeletal arrangement.

Distribution. Indian Ocean: Kerguelen I.; Heard I. (BourYEsnault \& Van Beveren 1982). South America: Chile (Desqueyroux 1976, Desqueyroux \& Moyano 1987); Magellan Strait (Pansini \& SARÀ 1999); South Georgia I.; South Orkney Is. (BurTon 1932 1934). Antarctica: Graham Land (DESQUeYrouX-FAúNDEZ 1989); Victoria Land (KirkPatrick 1907 1908; Burton 1929); Adelie Land (Burton 1938, Vacelet \& Arnaud 1972); Wilhelm II Land (Hentschel 1914); Knox Land (Burton 1938); Princess Ragnhild Land (Koltun 1964); Enderby Land; McRobertson Land (Koltun 1976); Weddell Sea (BArthel et al. 1990, 1997, Gutt \& Koltun 1995); Bransfield Strait (BurTon 1932, present study). Bathymetry: 18 m (KirKPATRICK 1907) to 1592 m (BurTon 1938).

\section{Suberitidae Schmidt, 1870 Homaxinella balfourensis (Ridley \& Dendy, 1886) Figs 45-49, Tab. III}

Axinella balfourensis Ridley \& Dendy, 1886: 480.

Homaxinella balfourensis; Lévi, 1964: 150, fig. 4, pl. I, fig. 4; Koltun, 1964: 84, pl. XIII, figs 11-12, 1976: 190; Vacelet \& Arnaud, 1972: 15; Boury-Esnault \& Van Beveren, 1982: 46, pl. VII, fig. 25, text-fig. 12a-b; Desqueyroux-Faúndez, 1989: 110, pl. II, fig. 8, pl. VII, figs 41-42; Pansini et al., 1994: 70; Barthel et al., 1997: 48; Cattaneo-Vietti et al., 1999: 540.

Further synonym see Koltun (1964).

Material studied. MCNPOR 3132, St. 5062, Elephant I.:

Revista Brasileira de Zoologia 24 (3): 687-708, setembro 2007 

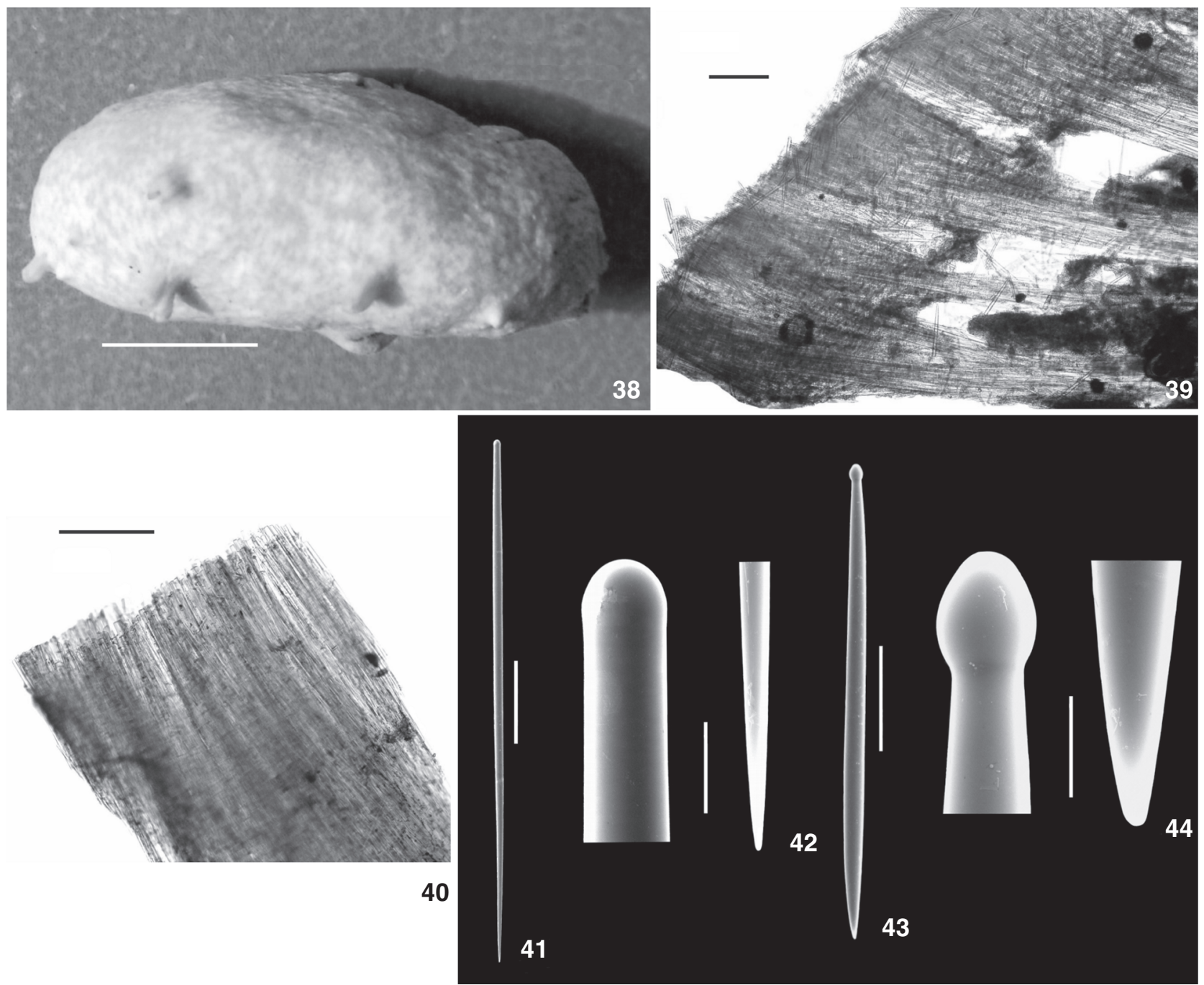

Figures 38-44. Polymastia invaginata: (38) preserved specimen; (39) skeleton; (40) spicules arrangement of papillae; (41) ectosomal tylostyles; (42) detail of ectosomal tylostyles extremities; (43) choanosomal tylostyles; (44) detail of choanosomal tylostyles extremities. Scale bars: (38) $1 \mathrm{~cm}$; (39), (40) $500 \mu \mathrm{m}$; (41) $200 \mu \mathrm{m}$; (42) $20 \mu \mathrm{m}$; (43) $75 \mu \mathrm{m}$; (44) $10 \mu \mathrm{m}$.

Table III. Homaxinella balfourensis: spicules measurements $(\mu \mathrm{m})$.

\begin{tabular}{cc}
\hline MCNPOR & Styles \\
\hline 3111 & $152-326.7-550 / 2.5-6.4-10.4$ \\
3130 & $171-382.6-608 / 2.5-6.6-11.5$ \\
3132 & $114-324.7-522.5 / 2.5-7.0-11.5$ \\
3369 & $133-323.9-560.5 / 2.5-7.1-10.4$ \\
\hline
\end{tabular}

$61^{\circ} 12^{\prime} \mathrm{S}-55^{\circ} 40^{\prime} \mathrm{W}, 98 \mathrm{~m}, 26 . \mathrm{II} .1987$, PROANTAR V; MCNPOR 3130, St. D, King George I.: $62^{\circ} 05^{\prime} \mathrm{S}-58^{\circ} 23^{\prime} \mathrm{W}, 20$ m, 26.II.1988, PROANTAR VI; MCNPOR 3369, St. D, King George I.: $62^{\circ} 05^{\prime}$ S$58^{\circ} 23^{\prime} \mathrm{W}, 25$ m, 21.I.1991, PROANTAR IX; MCNPOR 3111, St.
C, King George I.: $62^{\circ} 06^{\prime} \mathrm{S}-58^{\circ} 22^{\prime} \mathrm{W}, 28 \mathrm{~m}, 06 . \mathrm{III} .1988$, PROANTAR VI.

Material examined for comparison. Homaxinella balfourensis (Ridley \& Dendy, 1886), colleted by Swedish Antarctic Expedition, off Seymour Island, Antarctic Peninsula, slide BMNH 1933.3.17.104.

Description. (MCNPOR 3132) (Fig. 45) Arborescent specimen, with several ramifications; dimensions, in cm: 22.4 height, 16.8 width, branches ranging from 0.2-0.45 in diameter; microhispid surface, with slight spicule protraction; oscules not observed. Preserved material slightly elastic but firm in consistency; colour greyish beige. MCNPOR 3111, 3130 and 3369 are all amorphous fragments, bearing the same consistency and

Revista Brasileira de Zoologia 24 (3): 687-708, setembro 2007 

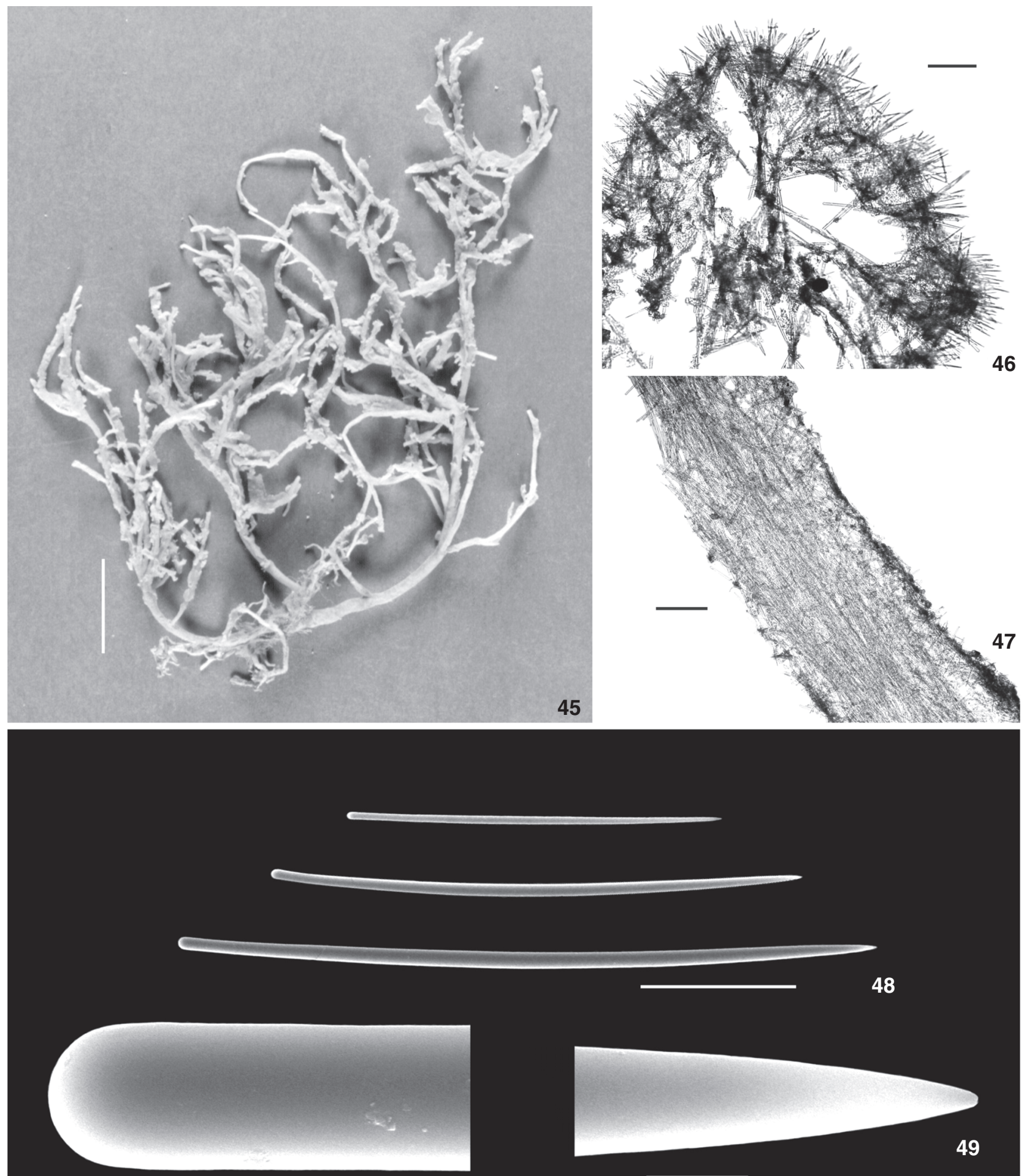

48

Figures 45-49. Homaxinella balfourensis: (45) preserved specimen; (46) transversal section of skeleton; (47) longitudinal section of skeleton; (48) styles; (49) detail of style extremities. Scale bars: (45) 3 cm; (46) $300 \mu \mathrm{m}$; (47) $500 \mu \mathrm{m}$; (48) $100 \mu \mathrm{m}$; (49) $5 \mu \mathrm{m}$.

Revista Brasileira de Zoologia 24 (3): 687-708, setembro 2007 
colour in comparison to MCNPOR 3132; the three samples are not ramified and each one consists in cylindrical structures with not more than $10 \mathrm{~cm}$ length and $0.3 \mathrm{~cm}$ in diameter.

Skeleton. In transverse section the ectosome is made by discrete bouquets, characterizing the superficial hispidation (Fig. 46). Choanosome in longitudinal section with a dense internal axial arrangement formed by multispicular tracts, a great amount of sponging and free spicules (Fig. 47).

Spicules. Megascleres: styles - straight to slightly curved (Fig. 48), extremities varying from acerate to hastate (114-339.5608/2.5-6.8-11.5 $\mu \mathrm{m}$ ) (Fig. 49). All measurements are given in table III.

Remarks. This species is very common in the Antarctic continent, and several studies have treated its chemical composition and ecology (Seldes et al. 1986, McClintock 1987, DaYton 1989, Cerrano et al. 2000, Wilkins et al. 2002).

Skeletal and spicular features observed in the studied material are in accordance with comparative material. The axial arrangement of the choanosome and general features of ectosomal region are identical in both specimens, as well as the spicules (remeasured in BMNH 1933.3.17.104: styles 247423.9-598.5/3.5-7.2-13.8 $\mu \mathrm{m})$.

Distribution. Indian Ocean: Kerguelen I. (Ridley \& Dendy 1886, 1887, Lévi 1964, Boury-EsNault \& VAN BeVEREn 1982). South America: South Georgia I. (BuRTon 1932, 1934). Antarctica: Graham Land (Topsent 1907, 1908, 1917); Victoria Land (KirKPATRICK 1908, Burton 1929, Pansini et al. 1994, Cattaneo-Vietti et al. 1999); Adelie Land (Vacelet \& Arnaud 1972); Wilhelm II Land (Hentschel 1914); Queen Mary Land; Knox Land; Banzare Land; Princess Elisabeth Land (Koltun 1964); Enderby Land (Koltun 1976); Weddell Sea (BARTHel et al. 1997); South Shetland Is.: Deception I. (Topsent 1917); Elephant I. (Desqueyroux-Faúndez 1989; present study); King George I. (present study). Bathymetry: $0 \mathrm{~m}$ (Desqueyroux-Faúndez 1989) to 550 m (Koltun 1964).

\section{Suberites montiniger Carter, 1880}

\section{Figs $50-53$}

Suberites montiniger Carter, 1880: 256; Topsent, 1915: 39; Burton, 1932: 335; Koltun, 1964: 25, 1976: 169; Gutt \& Koltun, 1995:

231; Barthel et al., 1997: 47; Cattaneo-Vietti et al., 1999: 540. Suberella topsenti Burton, 1929: 446, pl. IV, fig. 5.

Further synonym see Koltun (1964).

Material studied. MCNPOR 1988, St. 4872, Bransfield Strait: 632ㅇ's-62³1'W, 168 m, 13.II.1986, PROANTAR IV.

Description. (Fig. 50) Globular specimen, fixed to a rock fragment; dimensions, in cm: $2.5 \mathrm{~cm}$ height, $2.2 \mathrm{~cm}$ in diameter; slightly hispid surface, with slightly protruded spicules; only one oscule present $(0.2 \mathrm{~cm}$ in diameter), at the apex of sponge body. Preserved material hard consistency, colour brown.

Skeleton. (Fig. 51) Ectosome not specialized. Choanosome with spicules in confusion, densely arranged and positioned at diverse angles, mixed with abundant spongin. Several openings and canals could be observed along the choanosome.
Spicules. Megascleres: tylostyles - straights, slightly curved, sinuous or somewhat twisted (Fig. 52). Tyle ovalate, poorly developed, apical extremity varying from conical to acerate (Fig. 53): 330-364-410/7.5-8.8-10 $\mu \mathrm{m}$, tyle width 7.5-9.0-10 $\mu \mathrm{m}$.

Remarks. Suberites montiniger presents a taxonomic problem: originally the species was described by CARTER (1880) for the Barents Sea, Glacial Arctic Ocean; and later Topsent (1915) recorded it for Antarctica. Our data can shed no light on the question of this disjunct distribution; although the populations in these regions may be two distinct species, a revision to elucidate this question is beyond the scope of this work.

BURTON (1929), in describing Suberella topsenti for Antarctica, suggested it as a senior synonym of $S$. montiniger, alleging that the species described by CARTER (1880) showed certain differences in the skeleton. BuRTON (1932) compared his material with the sample described by CARTER (1880), considering both as identical samples. The lack of distinctive morphological characters in this species may have generated these conclusions, because the external morphology, skeletal architecture and spicules do not show variations that justify considering them as distinct taxa. The use of molecular techniques may assist in developing a more reliable diagnosis.

Distribution. Arctic Ocean, Barents Sea (CARTer 1880). South America: Falkland Is. (BurTon 1932); Burdwood Bank (Topsent 1915). Antarctica: Victoria Land (Burton 1929, Koltun 1964, Cattaneo-VietTi et al. 1999); McRobertson Land (Koltun 1976); Weddell Sea (GutT \& Koltun 1995, Barthel et al. 1997); Bransfield Strait (present study). Bathymetry: $91 \mathrm{~m}$ (BURTON 1929) to 424 m (GutT \& Koltun 1995).

\section{Halichondrida Gray, 1867 Halichondriidae Gray, 1867 Halichondria (Eumastia) attenuata (Topsent, 1915) Figs $54-57$}

Eumastia attenuata Topsent, 1915: 35-37, figs 1, 2a-b; Burton, 1932: 335, 1934: 44.

Material studied. MCNPOR 5484, St. 4874, Bransfield Strait: $63^{\circ} 25^{\prime} \mathrm{S}-62^{\circ} 19^{\prime} \mathrm{W}, 135 \mathrm{~m}, 14 . \mathrm{II} .1986$, PROANTAR IV.

Description. (Fig. 54) Irregular fragment; dimensions: 2.0 $\mathrm{x} 1.6 \mathrm{~cm}, 0.9 \mathrm{~cm}$ thick; slightly rugose surface, due to the presence of several ridges, not exceeding $0.1 \mathrm{~cm}$ height. The sample bears a very conspicuous cortex, detachable, slightly translucent, $<0.1 \mathrm{~cm}$ thick; oscules $<0.1 \mathrm{~cm}$ diameter. Preserved material lightly compressible in consistency; colour grayish white externally, light brown internally.

Skeleton. (Fig. 55) Ectosome formed by a cortical region, with a palisade of spicules, which protrude the surface, 530$870 \mu \mathrm{m}$ width. Below the cortex subectosomal openings or canals were observed, disposed regularly. Choanosome with spicules arranged in confusion, some of them positioned perpendicularly to the surface.

Spicules. Megascleres: oxeas - straight, smooth (Fig. 56),

Revista Brasileira de Zoologia 24 (3): 687-708, setembro 2007 

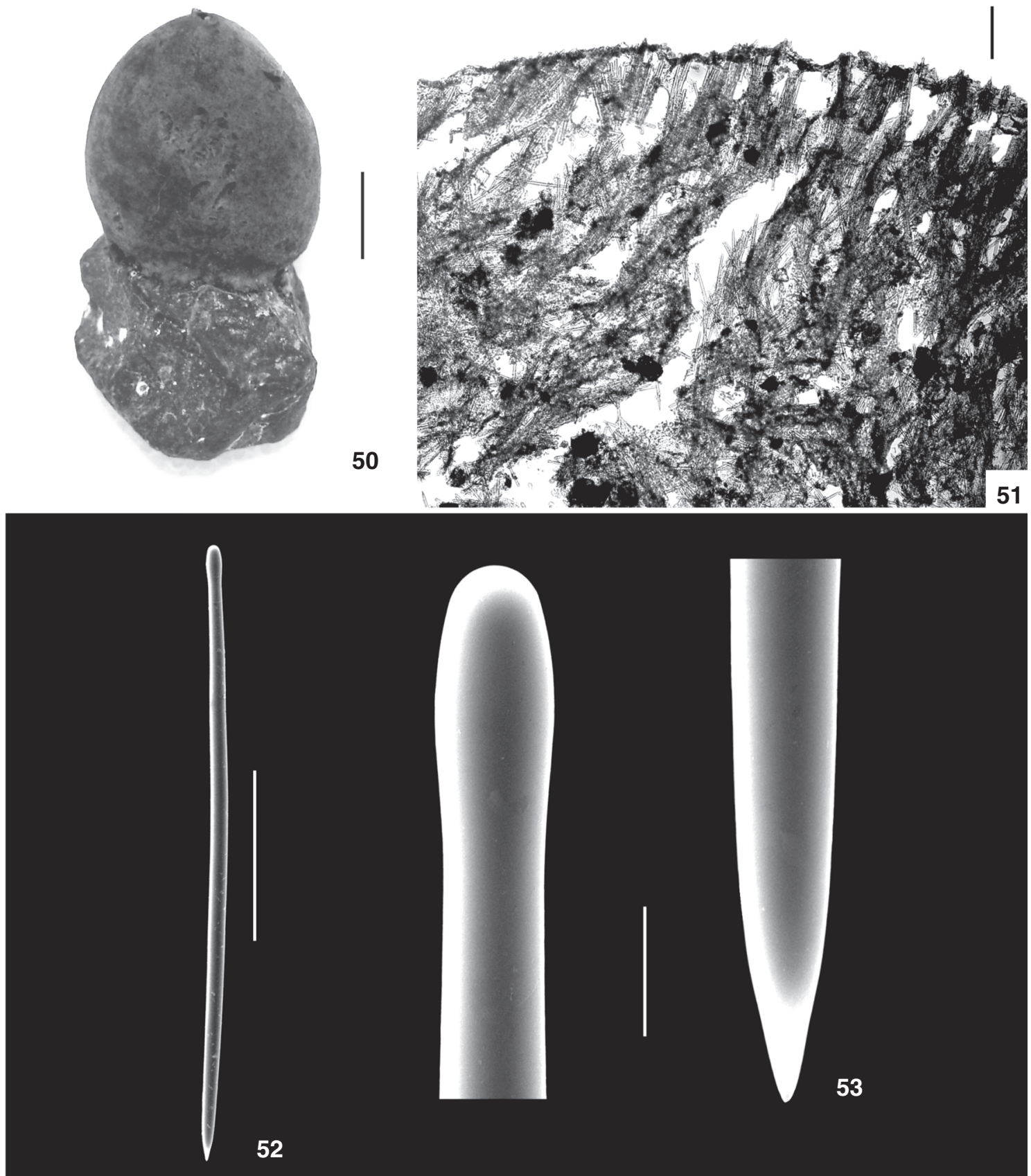

52

Figures 50-53. Suberites montiniger: (50) preserved specimen; (51) skeleton; (52) tylostyle; (53) detail of tylostyle extremities. Scale bars: (50) $1 \mathrm{~cm}$; (51) $300 \mu \mathrm{m}$; (52) $100 \mu \mathrm{m}$; (53) $10 \mu \mathrm{m}$.

extremities varying from acerate to conical, with predominance of the latter form (Fig. 57): 350-429.2-480/12.5-15.6-17.5 $\mu \mathrm{m}$.

Remarks. The skeletal architecture and spicules were photographed for the first time, in light microscopy and SEM, respectively.

TOPSEnt (1915) recorded the presence of well-developed papillae; however, in the material studied herein, the surface bears some tiny structures which are not true papillae. Measurements of the oxeas are very similar to those related by TOPSENT (1915), differing only by the presence of thicker spicules.

Distribution. South America: Falkland Is. (Topsent 1915, Burton 1932, 1934); South Georgia I. (BurTon 1934). Antarc-

Revista Brasileira de Zoologia 24 (3): 687-708, setembro 2007 

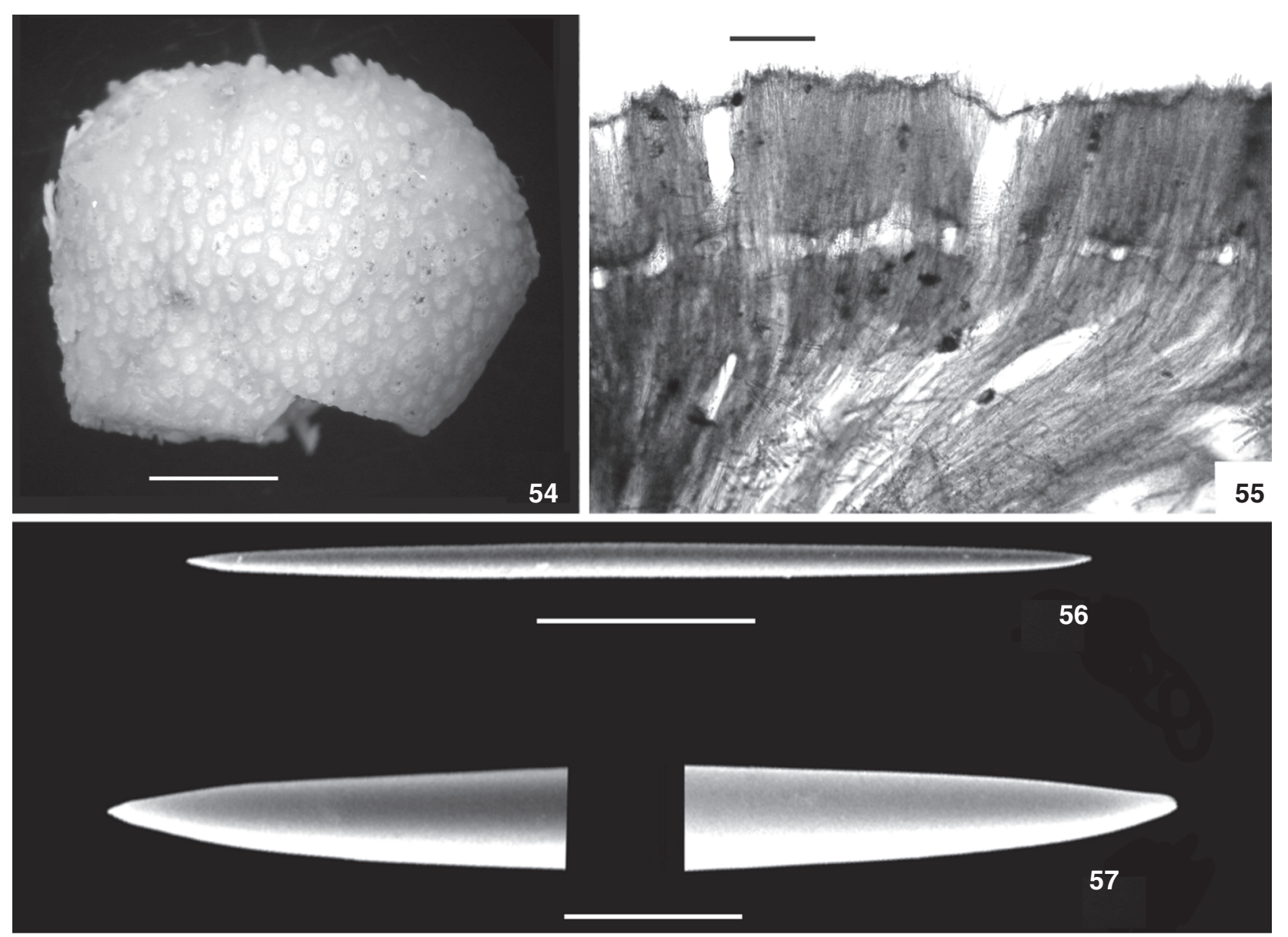

Figures 54-57. Halichondria (Eumastia) attenuata: (54) preserved specimen; (55) skeletal arrangement; (56) oxea; (57) detail of oxea extremities. Scale bars: (54) $0.5 \mathrm{~cm}$; (55) $600 \mu \mathrm{m}$; (56) $10 \mu \mathrm{m}$; (57) $20 \mu \mathrm{m}$.

tica: Bransfield Strait (present study). Bathymetry: 0-2 m (BuRTON 1932) to $135 \mathrm{~m}$ (present study).

\section{Haplosclerida Topsent, 1928 Haplosclerina Topsent, 1928 Chalinidae Gray, 1867}

\section{Haliclona (Soestella) chilensis (Thiele, 1905)} Figs 58-62

Reniera chilensis Thiele, 1905: 467, pl. 27, fig. 5, pl. 32, fig. 84. Haliclona chilensis; Burton, 1932: 265, 1934: 11; Desqueyroux

\& Moyano, 1987: 50.

Material studied. MCNPOR 3139, St. C, King George I.: 62 $06^{\prime}$ 'S-58 $22^{\prime} \mathrm{W}, 28 \mathrm{~m}, 06 . \mathrm{III} .1988$, PROANTAR VI.

Description. (Fig. 58) Specimen composed of unequal tubular projections bonded by the same base; dimensions: 5.2 $\mathrm{x} 3.6 \mathrm{~cm}, 4.0 \mathrm{~cm}$ height since the base; tubes ranging from 2.0$3.0 \mathrm{~cm}$ height, $1.2-1.8 \mathrm{~cm}$ width; surface optically smooth, slightly hispid to the touch; oscular openings at the apex of each tubular projection, $0.25-0.4 \mathrm{~cm}$ diameter. Preserved material slightly compressible in consistency; colour brown.

Skeleton. Ectosome formed by a tangential reticulation (Fig. 59), with multispicular rounded meshes, 100-420 $\mu \mathrm{m}$ diameter. Choanosome (Fig. 60) composed by a network of primary ascending tracts, paucispicular (02-05 spicules diameter), 10-50 $\mu \mathrm{m}$ width, connected by secondary tracts, unipaucispicular, 8.0-20 $\mu \mathrm{m}$ width; network bearing irregular meshes, rounded to triangular and/or polygonal, 80-180 $\mu \mathrm{m}$ in diameter. Scarce spongin, more visible at the nodes of the spicule tracts.

Spicules. Megascleres: oxeas - smooth, with a slight central bent, rarely fusiform (Fig. 61), extremities often acerate (Fig. 62), but rounded, conical and hastate forms may also occur: 137.5-163.9-180/2.5-8.9-12.5 $\mu \mathrm{m}$.

Remarks. The present sample is quite similar to the original description of THIELE (1905), with tubular projections bear- 


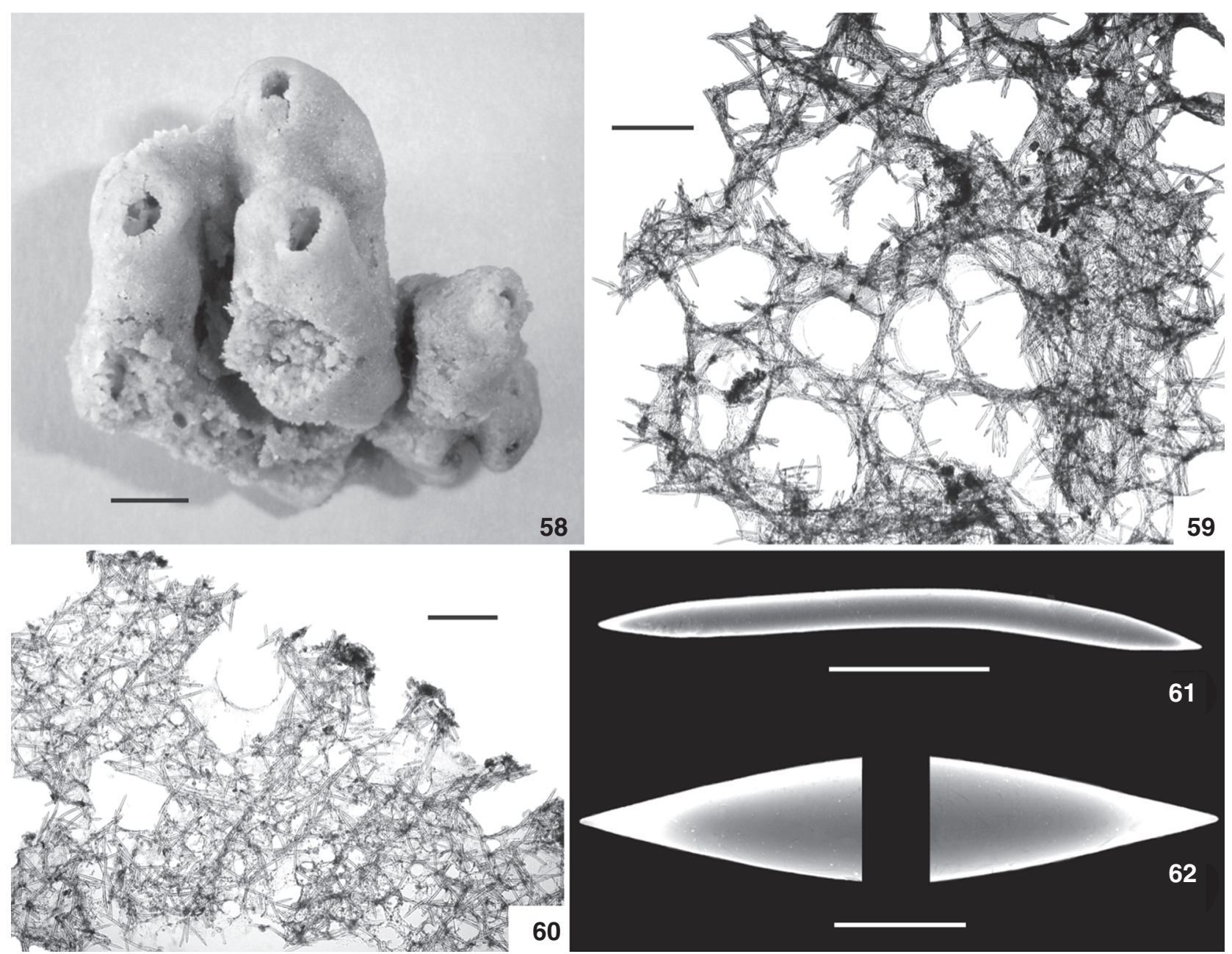

Figures 58-62. Haliclona (Soestella) chilensis: (58) preserved specimen; (59) tangential view of ectosome; (60) perpendicular section of choanosome; (61) oxea; (62) detail of oxea extremities. Scale bars: (58) $1 \mathrm{~cm}$; (59), (60) $500 \mu \mathrm{m}$; (61) $50 \mu \mathrm{m}$; (62) $10 \mu \mathrm{m}$.

ing an oscular opening at their apex. Together with such characteristics, the inclusion of this species in the subgenus Soestella is corroborated by the presence of a tangential ectosome composed by rounded apertures, in addition to possession of a choanosome with subanisotropic network of paucispicular primary lines, irregularly connected by secondary lines, and spongin at the nodes of the reticulation.

Dimensions of oxeas are very similar to those described by Thiele (1905); however, Burton (1932) recorded smaller oxeas. Thiele (op. cit.) observed oxeas with blunted ends, but in the present study extremities are more often pointed. These particularities are all interpreted as intraespecific variations.

Distribution. South America: Chile (Thiele 1905, Desqueyroux \& Moyano 1987); Falkland Is. (Burton 1932, 1934). Antarctica: South Shetland Is., King George I. (present study). Bathymetry: 15 m (BurTon 1934) to 75 m (BurTon 1932).

Revista Brasileira de Zoologia 24 (3): 687-708, setembro 2007

\section{Niphatidae Van Soest, 1980 Hemigellius bidens (Topsent, 1901) Figs 63-68}

Gellius bidens Topsent, 1901: VII, 1908: 21, pl. I, fig. 1, 1917: 77; Vacelet \& Arnaud, 1972: 19; Barthel et al., 1990: 123, 1997: 49.

Haliclona bidens; Koltun, 1964: 100.

Further synonym see Koltun (1964).

Material studied. MCNPOR 1981, 1989, St. 4869, Bransfield Strait: $63^{\circ} 33^{\prime} \mathrm{S}-59^{\circ} 15^{\prime} \mathrm{W}, 240 \mathrm{~m}$, 08.II.1986, PROANTAR IV.

Description. (MCNPOR 1989) (Fig. 63) Erect specimen; dimensions, in cm: 4.2 x 1.2, 0.3 thickness. Lightly rugose surface, hispid to the touch. Pores and oscules not observed. Preserved material friable in consistency; colour light brown with 


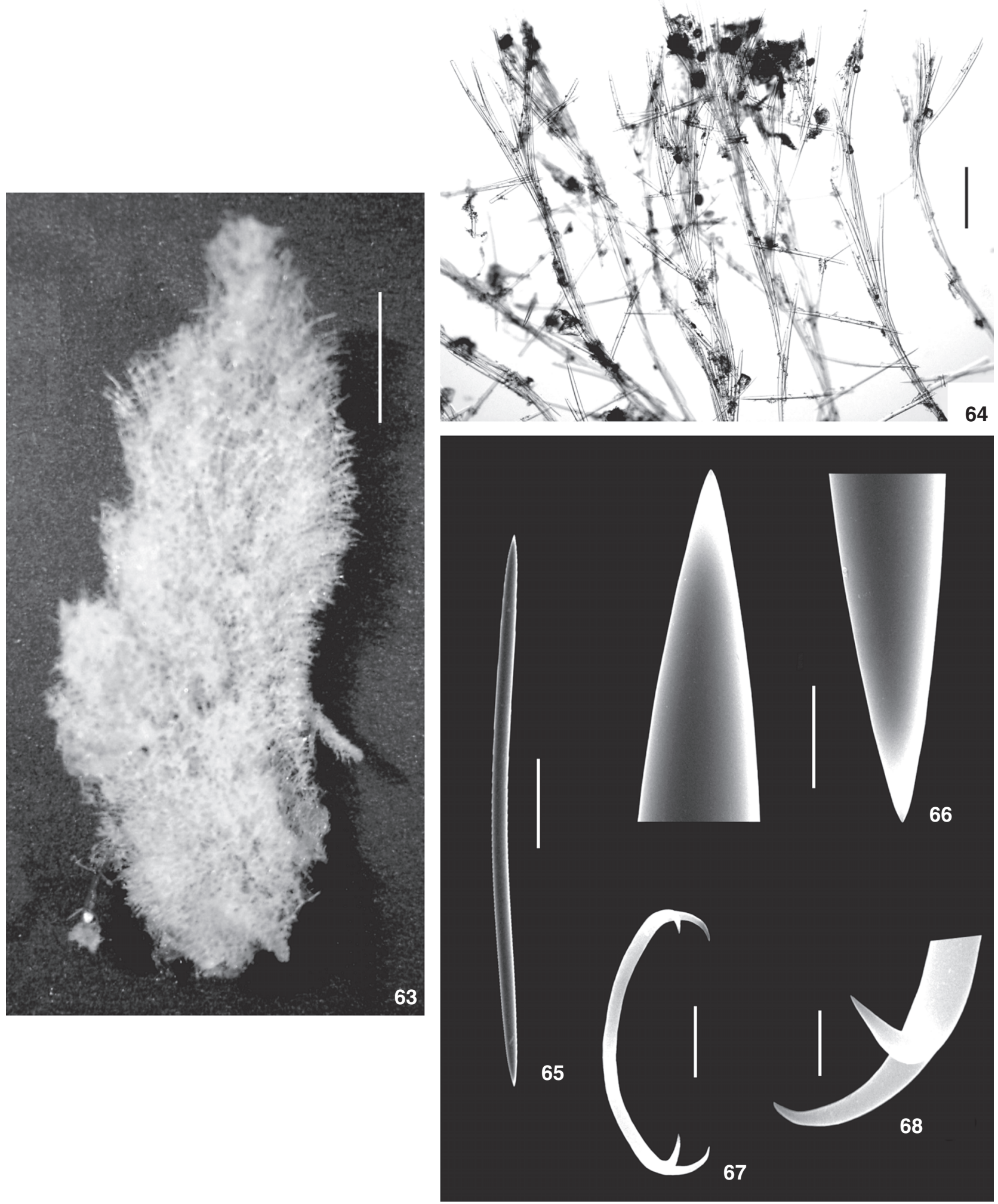

Figures 63-68. Hemigellius bidens: (63) preserved specimen; (64) skeleton; (65) oxea; (66) detail of oxea extremities; (67) sigma; (68) detail of sigma extremities. Scale bars: (63) $1 \mathrm{~cm}$; (64) $500 \mu \mathrm{m}$; (65) $100 \mu \mathrm{m}$; (66), (67) $10 \mu \mathrm{m}$; (68) $3 \mu \mathrm{m}$. 
clearer regions. MCNPOR 1981 is identical to MCNPOR 1989, only differing in having grey colour; dimensions, in cm: $4.0 \mathrm{x}$ 1.3, 0.4 thickness.

Skeleton. (Fig. 64) Ectosome without specialization, with megascleres in confusion. Choanosome with a reticulation composed by paucispicular tracts (02-03 spicules, 38-54 $\mu \mathrm{m}$ thickness), interconnected by 01-02 spicules, forming some isodictyal meshes (180-520 $\mu \mathrm{m}$ in diameter). Nodal spongin present, microscleres irregular or randomly occurring between the tracts.

Spicules. Megascleres: oxeas - smooth, straight or slightly curved (Fig. 65), acerate extremities (Fig. 66): 440-554.4-660/ 12.5-16.3-18.8 $\mu \mathrm{m}$ (MCNPOR 1981); 480-610.4-680/13.8-20.4$23.8 \mu \mathrm{m}$ (MCNPOR 1989). Microscleres: sigmas - smooth (Fig. 67), bearing bifid extremities (Fig. 68): 32.5-36.8-40 $\mu \mathrm{m}$

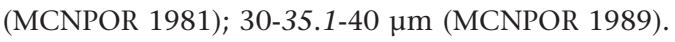

Remarks. Comparison with measurements provided by Topsent (1901) and Koltun (1964), the samples here studied have thicker spicules. For the first time the spicules were photographed by SEM, mainly detailing the extremity of the sigmas, which characterizes the species (Figs 67, 68).

Distribution. Antarctica: Bellinghausen Sea (Topsent 1901); Graham Land (Topsent 1908, 1917); Victoria Land (BuRTON 1929, 1938); Wilhelm II Land (Hentschel 1914); Adelie Land (VACElet \& Arnaud 1972); Weddell Sea (Barthel et al. 1990, 1997); Bransfield Strait (present study). Bathymetry: $30 \mathrm{~m}$ (Topsent 1908) to $550 \mathrm{~m}$ (TOPSENT 1901).

\section{Petrosina Boury-Esnault \& Van Beveren, 1982 Phloeodictyidae Carter, 1882 Calyx arcuarius (Topsent, 1913)}

\section{Figs 69-74, Tab. IV}

Gellius arcuarius Topsent, 1913: 638, pl. VI, fig. 11.

Calyx arcuarius; Burton, 1938: 9; Koltun, 1976: 196;

Desqueyroux, 1975: 71, pl. IV, figs 53-54; Barthel et al., 1990:

123, 1997: 49; Sarà et al., 1990: 254; Gutt \& Koltun, 1995:

231; Cattaneo-Vietti et al., 1999: 540.

Further synonym see Desqueyroux (1975).

Material studied. MCNPOR 3135, St. C, Livingston I.: 62 $40^{\circ}$ 'S-59³3'W, 270 m, 08.III.1987, PROANTAR V; MCNPOR

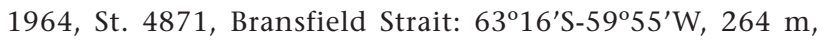
08.II.1986, PROANTAR IV; MCNPOR 1954, St. 4875, Bransfield Strait: $63^{\circ} 17^{\prime} \mathrm{S}-62^{\circ} 30^{\prime} \mathrm{W}, 157 \mathrm{~m}, 14 . \mathrm{II} .1986$, PROANTAR IV.

Description. (MCNPOR 1954) (Fig. 69) Fan-shaped sponge; dimensions, in cm: 27.5 height, 17.8 width, 0.5 thickness; optically smooth surface, on magnifying glass small spicule tract projections were observed; oscules present in both sides of the sponge, however more concentrated in basal region, in discrete stiffly volcanic projections, never exceeding $0.1 \mathrm{~cm}$ in diameter. Preserved material elastic and compressible in consistency; colour beige with greyish regions. MCNPOR 1964 and 3135 present the same form, texture and colour than
MCNPOR 1954; however the oscules were only observed in one of the sides of the surface; dimensions, in cm: 15.5 height, 6.5 width, 0.6 thickness, and 11 height, 6.5 width, 0.4 thickness, respectively.

Skeleton. Ectosome with a dense tangential reticulation, which are forming triangular to polygonal meshes (Fig. 70), 80-170 $\mu \mathrm{m}$ in diameter, unispicular tracts with nodal spongin. Choanosome formed by longitudinal multispicular tracts (Fig. 71), 75-140 $\mu \mathrm{m}$ thickness, which are interconnected by unispicular tracts bearing the same ectosomal features, only differing in having a more dense reticulation; toxas occurring around the tracts.

Spicules. Megascleres: oxeas - smooth, slightly curved and swollen (Fig. 72); acerate extremities (Fig. 73) (190-215.4-294.5/ 11.5-18-23 $\mu \mathrm{m}$ ). Microscleres: toxas (Fig. 74) - smooth, of varied opening angles, with sharp-pointed extremities (69-121.4-181.7/ 1.2-3.7-6.9 $\mu \mathrm{m})$. All measurements are given in table IV.

Table IV. Calyx arcuarius: spicules measurements $(\mu \mathrm{m})$.

\begin{tabular}{cll}
\hline MCNPOR & \multicolumn{1}{c}{ Oxeas } & \multicolumn{1}{c}{ Toxas } \\
\hline \multirow{2}{*}{1954} & $190-216.2-237.5 /$ & $78.2-115.2-147.2 /$ \\
& $16.1-19.4-23$ & $1.2-4.0-6.9$ \\
\multirow{2}{*}{1964} & $209-205-294.5 /$ & $69-119.1-181.7 /$ \\
& $11.5-17.2-19.6$ & $1.2-3.2-4.6$ \\
\multirow{2}{*}{3135} & $190-225-256.5 /$ & $80.5-129.8-174.8 /$ \\
& $11.5-18.4-20.7$ & $1.2-3.7-5.8$ \\
\hline
\end{tabular}

Remarks. Another conspicuous sponge in Antarctic waters; the list of synonyms includes C. stipitatus Topsent, 1916, which does not bear toxas; BurTON (1932), in comparing samples from both groups, observed that some features presented a subtle variation, in regard to spicules, external morphology and skeleton, and pointed out that such absence does not have taxonomic value.

Distribution. South America: South Georgia I.; Shag Rocks (Burton 1932, 1934). Antarctica: South Orkneys Is. (Topsent 1913); Graham Land (Topsent 1916, 1917); Victoria Land (BuRton 1929, SARÀ et al. 1990, CATtaneo-VietTi et al. 1999); Queen Mary Land (BurTon 1938); Knox Land; Banzare Land; Wilhelm II Land; McRobertson Land; Adelie Land (Koltun 1964); Enderby Land; Princess Elisabeth Land (Koltun 1976); Weddell Sea (BARTHel et al. 19901997 GutT \& Koltun 1995); South Shetland Is.: Deception I. (Desqueyroux 1975); Livingston I. (present study); King George I. (Koltun 1964); Bransfield Strait (present study). Bathymetry: 18 m (BurTon 1929) to 900 m (Koltun 1964).

\section{DISCUSSION}

Out of the 11 species described here, two are new records for Antarctica: Halichondria (Eumastia) attenuata and Haliclona (Soestella) chilensis. Both were formerly known only from the southernmost tip of South America, and their distribution is now 


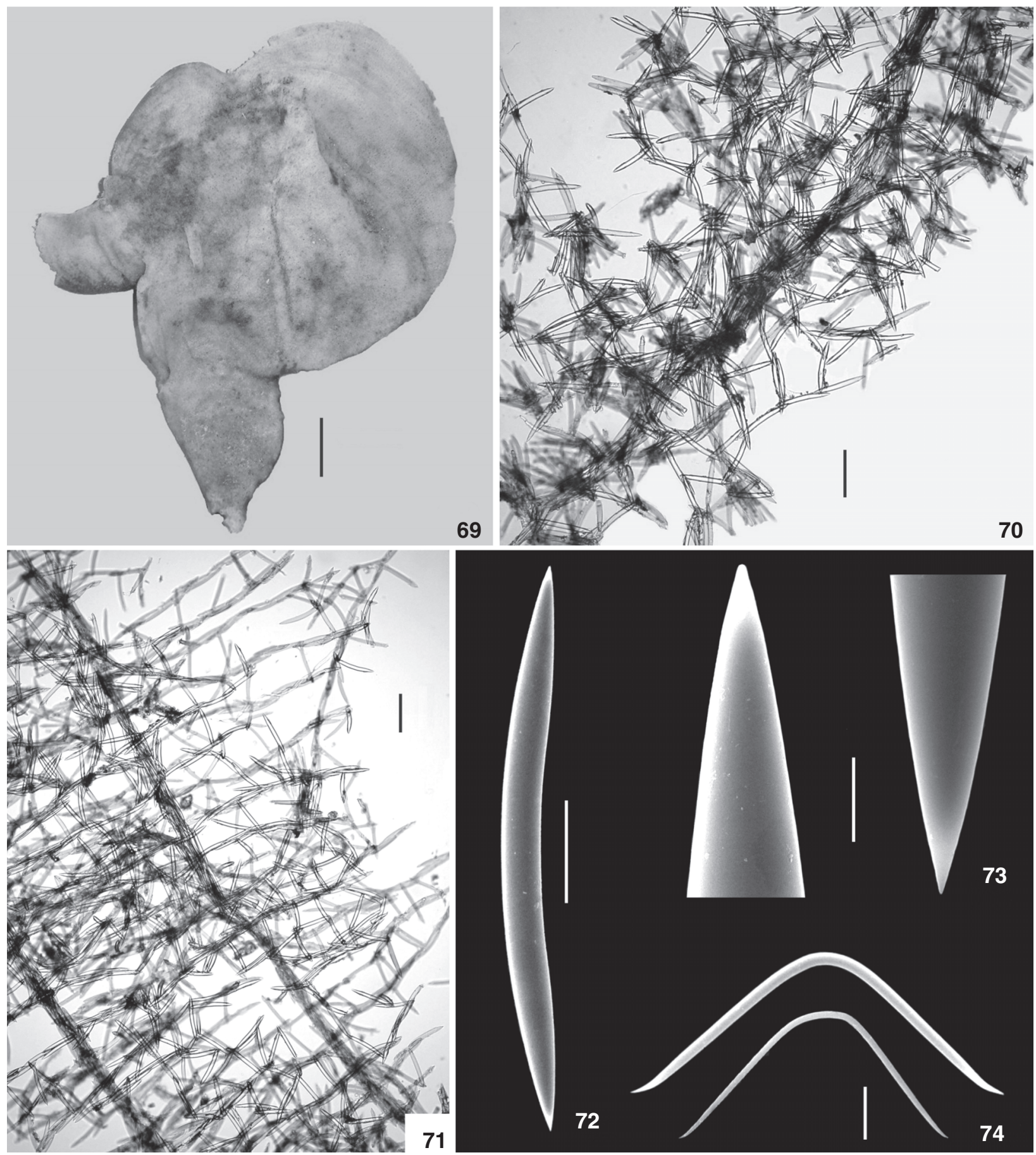

Figures 69-74. Calyx arcuarius: (69) preserved specimen; (70) tangential view of ectosome; (71) longitudinal section of choanosome; (72) oxea; (73) detail of oxea extremities; (74) toxas. Scale bars: (69) $3 \mathrm{~cm}$; (70), (71) $300 \mu \mathrm{m}$; (72) $50 \mu \mathrm{m}$; (73) $10 \mu \mathrm{m}$; (74) $20 \mu \mathrm{m}$.

extended to the South Shetland Islands and vicinity. The species studied generally occur off the coasts of Chile and Argentina, the Falkland Islands, Magellan Strait and Kerguelen Island; this study corroborated the affinities of this sponge fauna with areas of the southern coasts of Chile and Argentina, the Magellan Strait and some islands of the Scotia Arc (South Georgia, South Orkneys

Revista Brasileira de Zoologia 24 (3): 687-708, setembro 2007 
and South Sandwich Islands). The continuity of the Antarctic fauna in this region is explained by the existing geological connection between the continents (BARNES 2005).

Knowledge of the local benthic diversity in the South Shetland Is. and vicinities was expanded by the records of Tethyopsis longispinum, Suberites montiniger and Hemigellius bidens. Tethyopsis longispinum and Halichondria (Eumastia) attenuata also showed new bathymetric limits.

\section{ACKNOWLEDGEMENTS}

We thank Edmundo Nonato (Instituto Oceanográfico da Universidade de São Paulo, IOUSP), for making possible the donation of all Porifera specimens collected by PROANTAR for inclusion in MCNPOR. We thank Clare Valentine (The Natural History Museum) for the loan of comparative material; Eduardo Hajdu (Museu Nacional, Universidade Federal do Rio de Janeiro, Brazil) and Ruth Desqueyroux-Faúndez (Museum d'Histoire Naturelle de Genève, Geneva, Switzerland) for help in bibliography. We also thank CAPES and CNPq (Brazil) for research grants.

\section{REFERENCES}

BARNES, D.K.A. 2005. Changing chain: past, present and future of the Scotia Arc's and Antarctica's shallow benthic communities, p. 65-89. In: W.E. ArNTZ; G.A. Lovrich \& S. Thatje (Eds). The Magellan-Antarctic connection: links and frontiers at high southern latitudes. Scientia Marina 69, Suppl. 2, 374p.

Barthel, D.; O. Tendal \& K. Panzer. 1990. Ecology and taxonomy of sponges in the eastern Weddell Sea shelf and slope communities. Berichte zur Polarforschung 68: 120-130.

Barthel, D.; J. Gutt \& O.S. Tendal. 1991. New information on the biology of Antarctic deep-water sponges derived from underwater photography. Marine Ecology Progress Series 69: 303-307.

Barthel, D.; O. Tendal \& S. Gatti. 1997. The Sponge Fauna of the Weddell Sea and Its Integration in Benthic Processes. Berichte zur Polarforschung 249: 44-52.

Boury-Esnault, N. \& M. Van Beveren. 1982. Les Démosponges du Plateau Continental de Kerguelen-Heard. Comité National Français des Rechearches Antarctiques 52: 1-175.

Broendsted, H.V. 1926. Antarctic and subantarctic sponges collected by S. Wallin (1924). Arkiv för Zoologi 19A: 1-6.

Burton, M. 1929. Porifera. Part II. Antarctic Sponges. National History Reports of the British Antarctic "Terra Nova" Expedition, 1910, Zoology 6 (4): 393-458.

Burton, M. 1932. Sponges. Discovery Reports 6: 237-392.

Burton, M. 1934. Sponges. Further Zoological Results of the Swedish Antarctic Expedition 1901-1903 3 (2): 1-58.

Burton, M. 1938. Non-calcareous sponges. Australasian Antarctic Expedition 1911-1914, Scientific Reports, Series C - Zoology and Botany 9 (5): 3-22.

Burton, M. 1940. Las esponjas marinas del Museo Argentino de Ciencias Naturales. Anales del Museo Argentino de Ciencias Naturales "Bernardino Rivadavia" 40: 95-121.

Calcinai, B. \& M. Pansini. 2000. Four new demosponge species from Terra Nova Bay (Ross Sea, Antarctica). Zoosystema 22 (2): 369-381.

Carter, H.J. 1872. On two new Sponges from the Antarctic Sea, and on a new Species of Tethya from Shetland; together with Observations on the Reproduction of Sponges commencing from Zygosis of the Sponge-animal. Annals and Magazine of Natural History (4) 9 (54): 409-435.

Carter, H.J. 1879. Sponges (from Kerguelen Island). Philosophical Transactions of the Royal Society of London 168: 286-288.

CARTer, H.J. 1880. Spongia, p. 286-287. In: W.S.M. D’URban (Ed.). The Zoology of Barents Sea. Annals and Magazine of Natural History (5) 6 (34): 253-277.

Cattaneo-Vietti, R.; G. Bavestrello; C. Cerrano; E. Gaino; L. Mazzella; M. Pansini \& M. SARÀ. 1999. The Role of Sponges in the Terra Nova Bay Ecosystem, p. 539-549. In: F. FARANDA (Ed.). Benthic Ecology of Terra Nova Bay. Berlin, SpringerVerlag, 549p.

Cerrano, C.; G. Bavestrello; B. Calcinai; R. Cattaneo-Vietti \& A. SARÀ. 2000. Asteroids eating sponges from Tethys Bay, East Antarctica. Antarctic Science 12 (4): 425-426.

DAYTON, P.K. 1989. Interdecadal Variation in an Antarctic Sponge and Its Predators from Oceanographic Climate Shifts. Science 245: 1484-1486.

Desqueyroux, R. 1972. Gubki (Porifera) sobranie u Iuynix Shetlandskix Ostrovof y Antarktichescovo poluostrovo. Issledovania Fauni Morei 11 (19): 49-55.

Desqueyroux, R. 1975. Esponjas (Porifera) de la region antartica chilena. Cahiers de Biologie Marine 16: 47-82.

Desqueyroux, R. 1976. Démosponges signalées pour la région dês Canaux du Chili. Cahiers de Biologie Marine 17: 93-109.

Desqueyroux, R. \& H. Moyano. 1987. Zoogeografia de Demospongias chilenas. Boletin de la Sociedad de Biologia de Concepción 58: 39-66.

Desqueyroux-Faúndez, R. 1989. Demospongiae (Porifera) del litoral chileno antártico. Serie Científica del Instituto Antártico Chileno 39: 97-158.

GutT, J. \& W.M. Koltun. 1995. Sponges of the Lazarev and Weddell Sea, Antarctica: explanations for their patchy occurrence. Antarctic Science 7 (3): 227-234.

Hentschel, E. 1914. Monaxone Kieselschwämme und Hornschwämme der Deutschen Südpolar-Expedition 19011903. Deutsche Südpolar-Expedition, 1901-1903 15 (1): 35-141.

Kirkpatrick, R. 1905. On the oscules of Cinachyra. Annals and Magazine of Natural History (7) 16 (96): 662-667.

Kirkpatrick, R. 1907. Preliminary report on the Monaxonellida of the National Antarctic Expedition. Annals and Magazine of Natural History (7) 20 (117): 271-291.

KirkPATRICK, R. 1908. Porifera (Sponges). II. Tetraxonida, Dendy. 
National Antarctic Expedition 1901-1904 4: 1-56.

Koltun, W.M. 1964. Sponges of the Antarctic. I. Tetraxonida and Cornacuspongida. Biological Reports of the Soviet Antarctic Expedition (1955-1958). Issledovania Fauni Morei 2: 6-116.

Koltun, W.M. 1969. Porifera. Antarctic Map Folio Series 11: 13-14.

Koltun, W.M. 1976. Porifera - Part I: Antarctic Sponges. B.A.N.Z. Antarctic Research Expedition, Reports, Series B (Zoology and Botany) 9 (4): 147-198.

Lendenfeld, R. Von. 1907. Tetraxonia der Deutschen SüdpolarExpedition 1901-1903. Deutsche Südpolar-Expedition, 1901-1903 9 (1): 303-342.

LÉvi, C. 1964. Éponges de la Baie du Morbihan (Iles de Kerguelen). Comité National Français des Rechearches Antarctiques 1 (8): 149-155.

McClinTock. J.B. 1987. Investigation of the relationship between invertebrate predation and biochemical composition, energy content, spicule armament and toxicity of benthic sponges at McMurdo Sound, Antarctica. Marine Biology 94: 479487.

McClintock, J.B.; C.D. amsler; B.J. Baker \& R.W.M. Van Soest. 2005. Ecology of Antarctic Marine Sponges: an Overview. Integrative and Comparative Biology 45: 359-368.

Mothes, B.; M.A. Campos; C.B. Lerner \& Ferreira-Correia, M.M. 2004. Esponjas (Demospongiae, Halichondrida) da costa do Maranhão, Brasil. Iheringia, Série Zoologia, 94 (2): 149-154.

Mothes-DE-Moraes, B. 1978. Esponjas tetraxonidas do litoral sulbrasileiro: II. Material coletado pelo N/Oc. "Prof. W. Besnard" durante o programa RS. Boletim do Instituto de Oceanografia 27 (2): 57-78.

Pansini, M; B. Calcinai; R. Cattaneo-Vietti \& M. Sarà. 1994. Demosponges from Terra Nova bay (Ross Sea, Antarctica): 1987/88 and 1989/89 P.N.R.A. Expeditions. National Scientific Comission for Antarctica 3: 67-100.

PANSINI, M. \& M. SARÀ. 1999. Taxonomical and biogeographical notes on the sponges of the Straits of Magellan, p. 203-208. In: W.E. Arntz \& C. Ríos (Eds). Magellan-Antarctic: Ecosystems that drifted apart. Scientia Marina 63 (Supplement 1), 518p.

Ridley, S.O. \& A. Dendy. 1886. Preliminary Report on the Monaxonida collected by H.M.S. 'Challenger'. Annals and Magazine of Natural History (5) 18 (107): 325-351, 470493.

Ridley, S.O. \& A. Dendy. 1887. Report on the Monaxonida collected by H.M.S. 'Challenger' during the years 1873-1876. Report on the Scientific Results of the Voyage of H.M.S. 'Challenger' 1873-1876, Zoology 20: 1-279.

Ríos, P.; F.J. CRistobo \& V. URgorri. 2004. Poecilosclerida (Porifera, Demospongiae) collected by the spanish Antarctic expedition BENTART-94. Cahiers de Biologie Marine 45: 97-119.

SarÀ, M.; A. BalduzZi; M. Barbieri; G. Bavestrello; C.N. Bianchi; F. Boero; R. Cattaneo-Vietti; G. Corriero; C. Morri \& M. Pansini.
1990. Hard bottom zoobenthos: an analysis of its composition, distribution and of the adaptative strategies of the species. National Scientific Comission for Antarctica 2: 249-260.

SarÀ, M; A. Balduzzi; M. Barbieri; G. Bavestrello \& B. Burlando. 1992. Biogeographic traits and checklist of Antarctic demosponges. Polar Biology 12: 559-585.

Seldes, A.M.; J. Rovirosa; A. San Martin \& E.G. Gros. 1986. Steroids from aquatic organisms-XII. Sterols from the antarctic sponge Homaxinella balfourensis (Ridley and Dendy). Comparative Biochemistry and Physiology 83B (4): 841-842.

SiLva, C.M.M. \& B. Mothes. 1996. SEM analysis: an important instrument in the study of marine sponges biodiversity. Acta microscopica 5(B): 188-189.

Soest, R.W.M. Van \& K. RÜtzler. 2002. Family Tetillidae, p. 8598. In: J.N.A. Hooper \& R.W.M. VAN SOEST (Eds). Systema Porifera: a guide to the classification of sponges. New York, Kluwer Academic, vol. 1, XIX+1101p.

Soest, R.W.M. Van; N. Boury-Esnault; D. Janussen \& J.N.A. Hooper. 2005. World Porifera Database. Available in the World Wide Web at: http://www.vliz.be/vmdcdata/porifera [accessed in 25/III/2007].

Sollas, W.J. 1886. Preliminary account of the Tetraxinellid sponges dredged by H.M.S. 'Challenger' 1872-1876. Part I. The Choristida. Scientific Proceedings of the Royal Dublin Society 5: 177-199.

SolLAS, W.J. 1888. Report on the Tatractinellida collected by H.M.S. 'Challenger' during the years 1873-1876. Report on the Scientific Results of the Voyage of H.M.S. 'Challenger' 1873-1876, Zoology 25: 1-458.

Thiele, J. 1905. Die Kiesel- und Hornschwämme der Sammlung Plate. Zoologische Jahrbücher 6: 407-496.

Topsent, E. 1901. Spongiaires. Résultats du voyage du S.Y. Belgica en 1897-1898-1899 6-9: 1-54.

Topsent, E. 1907. Poecilosclérides nouvelles recueillies par le Français dans l'Antarctique. Bulletin du Muséum National d'Histoire Naturelle 13: 69-76.

Topsent, E. 1908. Spongiaires. Expédition Antarctique Française (1903-1905) commandée par le Dr. Jean Charcot 4 : $1-37$.

Topsent, E. 1913. Spongiaires de l'Expédition Antarctique Nationale écossaise. Transactions of the Royal Society of Edinburgh 49 (3): 579-643.

Topsent, E. 1915. Spongiaires recueillies par la Scotia dans l'Antarctique (1903-1904). Transactions of the Royal Society of Edinburgh (Supplément) 51: 35-43.

Topsent, E. 1916. Diagnoses d'Eponges recueillies dans l'Antarctique par le Pourquoi pas?. Bulletin du Muséum National d'Histoire Naturelle (1) 22 (3): 163-172.

Topsent, E. 1917. Spongiaires. Deuxième Expédition Antarctique Française (1908-1910) commandée par le Dr. Jean Charcot. Paris, Masson et Cie, 88p.

Vacelet, J. \& F. ARnaud. 1972. Invertébrés Marins des XII ${ }^{\text {ème }}$ et 
XVème Expéditions Antarctiques Françaises en Terre Adélie.

2. Démosponges. Tethys Supplement 4: 9-24.

Wilkins, S.P.; A. J. Blum; D.E. Burkepile; T.J. Rutland; A. Wierzbicki;
M. Kelly \& M.T. Hamann. 2002. Isolation of an antifreeze peptide from the Antarctic sponge Homaxinella baufourensis. Cellular and Molecular Life Sciences 59: 2210-2215.

Received in 21.XI.2006; accepted in 15.VIII.2007. 